\title{
In situ feeding physiology and grazing impact of the appendicularian community in temperate waters
}

\author{
Ángel López-Urrutia ${ }^{1,3, *}$, Xabier Irigoien ${ }^{2,4}{ }^{,}$José Luis Acuña $^{1}{ }^{1}$ Roger Harris ${ }^{2}$ \\ ${ }^{1}$ Area de Ecología, Departamento de Biología de Organismos y Sistemas, Universidad de Oviedo, C/Catedrático Rodrigo \\ Uría (s/n), Oviedo 33071, Spain \\ ${ }^{2}$ Plymouth Marine Laboratory, Prospect Place, West Hoe, Plymouth PL1 3DH, United Kingdom \\ ${ }^{3}$ Present address: Plymouth Marine Laboratory \\ ${ }^{4}$ Present address: Technological Institute for Fisheries and Food (AZTI), Herrera Kaia Portualde z/g, 20110 Pasaia, Spain
}

\begin{abstract}
The physical and biological factors affecting the abundance and ingestion rates of different appendicularian species were investigated from April 1999 to May 2000 at a coastal station in the English Channel and on a transect of 3 stations across the shelf in the central Cantabrian Sea. Individual gut chlorophyll and gut food volume contents were used to determine the ingestion rates on autotrophic prey and on total particulate material. Body size was the variable explaining most of the variability in gut contents. For most species, over $60 \%$ of the ingested material came from nonchlorophyll-containing prey. Appendicularian community grazing impact was higher at the oceanic stations during early spring and autumn, with maximum values close to $10 \%$ of the total phytoplankton biomass removed daily. Oikopleura longicauda and O. fusiformis were the species with the highest grazing impact. During the study period, appendicularians removed an average of $8 \%$ of the primary production (PP) measured at the only station for which we have concurrent measurements. Our results suggest that the bulk of appendicularian populations resides in the surface mixed layer and that their grazing rates increase with increasing PP. However, the percentage of the PP removed by the appendicularian community decreases with increasing productivity, indicating that their grazing impact is relatively more important under oligotrophic conditions. Appendicularians could account for close to $40 \%$ of the total mesozooplankton grazing.
\end{abstract}

KEY WORDS: Appendicularian · Gut content $\cdot$ Feeding $\cdot$ Grazing $\cdot$ Tunicate $\cdot$ Oikopleura $\cdot$ Fritillaria Resale or republication not permitted without written consent of the publisher

\section{INTRODUCTION}

Our knowledge on the importance of appendicularians in marine planktonic food webs is still limited (Bone 1998, Calbet 2001). Their role in the classical herbivorous food web is uncertain because of their ability to feed on particles smaller than $5 \mu \mathrm{m}$ (Cushing 1989). This nutritional adaptation has led several authors to propose that appendicularians should play a significant role in microbial-driven oligotrophic systems, where the majority of the particle biomass resides in the $<5 \mu \mathrm{m}$ size fraction (Deibel 1998, Gorsky \& Fenaux 1998). However, the fact that reports of high appendicularian densities are mainly limited to highly

*Email: alop@pml.ac.uk eutrophic, neritic waters (e.g. Seki 1973, Uye \& Ichino 1995, Hopcroft \& Roff 1998, Nakamura 1998) is at odds with the notion (mostly based on laboratory experimentation), that they are microbial-loop feeders. Clearly, measurements of appendicularian feeding at different temporal and spatial scales are required to ascertain their role as grazers in pelagic food webs.

Although some information is available on factors affecting feeding rates under controlled laboratory conditions (e.g. Acuña \& Kiefer 2000), this approach does not allow the determination of the relative importance of these factors in the field (Peters \& Downing 1984). On the other hand, in situ information is particularly scarce, studies are commonly restricted in time 
or space, and information on the feeding rates of some abundant species is completely lacking. Wide spatiotemporal and species-specific coverage requires a technique of easy application that is suitable for routine sampling from ships. The gut chlorophyll-content technique (Mackas \& Bohrer 1976) meets these requirements, and has provided much of the auto- and synecological information available for crustacean zooplankton. This technique has 2 major drawbacks: the uncertainty about the degree of pigment degradation during digestion, and the fact that it only evaluates the amount of autotrophic (i.e. chlorophyll-containing) prey (Båmstedt et al. 2000). Although chlorophyll degradation in appendicularians is less variable than in copepods (Bochdansky et al. 1998), appendicularians are known to feed on a wide range of nonautotrophic material (e.g. detritus: Gerber \& Marshall 1974, Dagg et al. 1996, and heterotrophic flagellates: Urban et al. 1992). As an alternative to the gut-pigment technique, Tackx et al. (1995) proposed a method to measure ingestion rates of total particulate matter

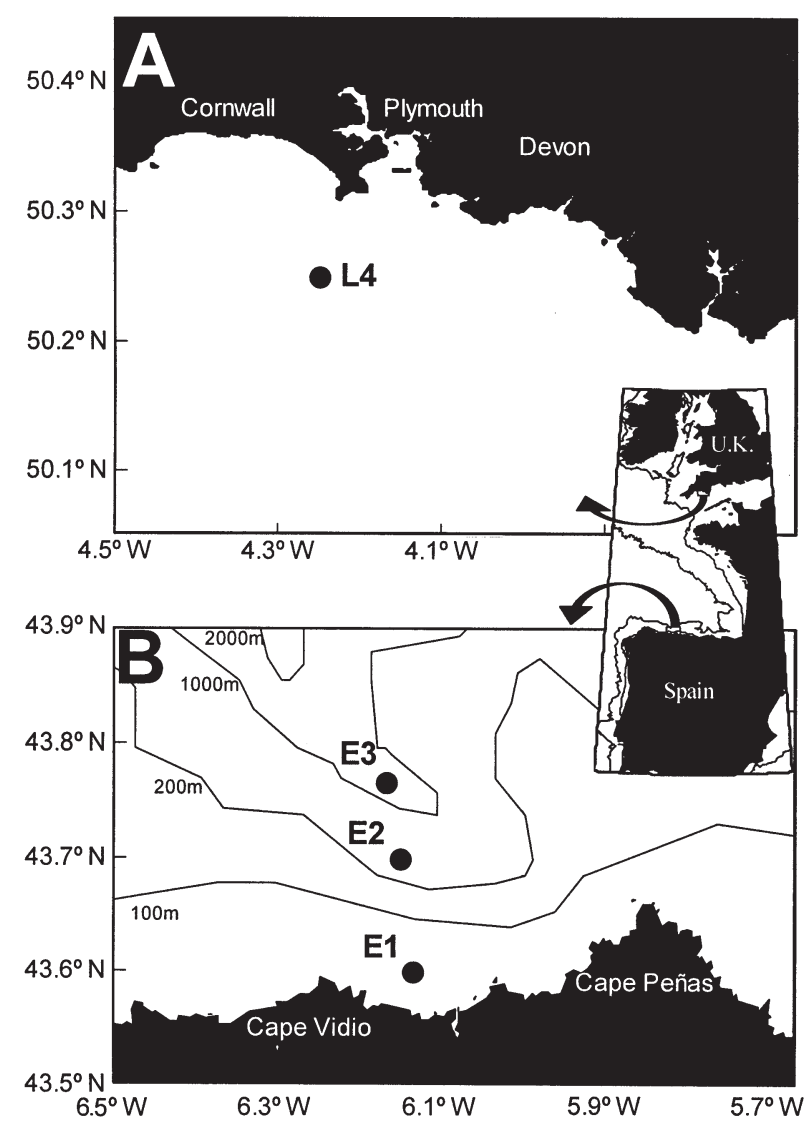

Fig. 1. Study sites. (A) Stn L4 in coastal waters of English Channel, approx. $55 \mathrm{~m}$ water depth; (B) Stns E1, E2 and E3 in the Cantabrian Sea (NW Spain), approx. 50, 120 and $1000 \mathrm{~m}$ depth respectively based on the volume of food in the gut instead of the gut-chlorophyll content, and used it in combination with Coulter Counter measurements and bottle incubations to assess feeding selectivity by estuarine copepods. Bochdansky \& Deibel (1999) also suggested that the volume of food in the gut of the cold-water appendicularian Oikopleura vanhoeffeni could be used to estimate its ingestion rate.

We have employed both approaches in parallel, gut chlorophyll and gut food-volume content techniques. Since our idea was to examine how the grazing rates relate to the widest possible range of environmental parameters, we conducted our seasonal study at 4 stations representative of geographically and functionally contrasting habitats. Lastly, we have combined our ingestion rate estimates with appendicularian species abundances to determine the impact of appendicularian grazing on primary producers and on total particulate material.

\section{MATERIALS AND METHODS}

Data collection. Samples were collected between April 1999 and February 2000 at weekly intervals from a coastal station in the English Channel (L4; Fig. 1A), and on a monthly basis from April 1999 to May 2000 on a transect of 3 stations across the shelf in the central Cantabrian Sea (E1, E2 and E3, Fig. 1B). At each station, vertical profiles of chlorophyll $\left(\mu g \mathrm{l}^{-1}\right)$, salinity (psu) and temperature $\left({ }^{\circ} \mathrm{C}\right)$ were obtained using a SBE 25 CTD (Sea Bird Instruments) in the Cantabrian Sea and a CTD probe developed for the Undulating Oceanographic Recorder (Aiken \& Bellan 1990) in the English Channel. Standard deviation of temperature $\left({ }^{\circ} \mathrm{C}\right)$ over the upper $50 \mathrm{~m}$ of the water column was used as an index of the degree of thermal stratification, since temperature differences and therefore the standard deviation of the vertical temperature profile increase with increasing water-column stratification (Valdes \& Moral 1998). The depth of the mixed layer was calculated following Sprintall \& Tomczak (1992) using a temperature difference of $0.5^{\circ} \mathrm{C}$. Seawater collected from $10 \mathrm{~m}$ with a 51 Niskin bottle was used for size-fractionated chlorophyll a equivalents and for particle volume measurements. Two $250 \mathrm{ml}$ water samples, one of them prefiltered using a $30 \mu \mathrm{m}$ Nitex mesh, were filtered through $25 \mathrm{~mm}$ Whatman GF/F filters to determine $>0.7$ and 0.7 to $30 \mu \mathrm{m}$ chlorophyll concentrations (total and $<30$ fractions respectively, $\mu \mathrm{g}^{-1}$ ) using the standard fluorometric procedure (US Environmental Protection Agency Method 445.0). The chlorophyll fraction $>30 \mu \mathrm{m}$, estimated as the difference between the total and $<30 \mu \mathrm{m}$ fractions, was considered to represent non-ingestible material (larger 
than the pore width of the inlet filter of the house: Flood \& Deibel 1998). Total particle concentration $\left(\mu \mathrm{m}^{3}\right.$ $\mathrm{ml}^{-1}$ ) in the size range 2 to $30 \mu \mathrm{m}$ ESD (equivalent spherical diameter) was measured using a Coulter Multisizer II fitted with a $70 \mu \mathrm{m}$ aperture tube. Chlorophyll and particle concentrations measured at $10 \mathrm{~m}$ were considered representative of the surface mixed layer, where appendicularians were mainly present (see 'Results' and Fig. 2). In this regard, we found no significant difference between the integrated total chlorophyll concentrations for the upper mixed layer obtained using data collected at $10 \mathrm{~m}$ depth intervals and those obtained assuming a constant chlorophyll concentration equal to that obtained from the $10 \mathrm{~m}$ sample (result not shown). Primary production (PP; mg C m${ }^{-2} \mathrm{~d}^{-1}$ ) was measured at Stn E2 using water collected at depths corresponding to 100 and $1 \%$ of the surface irradiance and to the chlorophyll maximum (Serret et al. 1999).

Vertical hauls using a $200 \mu \mathrm{m}$ WP-2 net, from $50 \mathrm{~m}$ at the shallow stations (L4 and E1: Fig. 1) and $100 \mathrm{~m}$ in deep-oceanic stations (E2 and E3: Fig. 1) to the surface, were used to collect samples for determination of appendicularian abundance and for gut-content analysis. After collection, the entire cod end was diluted in filtered seawater (Whatman GF/F), then brought to a known volume (usually $200 \mathrm{ml}$ ), and five $10 \mathrm{ml}$ aliquots were removed with a wide-bore automatic pipette, placed in criovials, and immediately frozen with liquid nitrogen.

In the laboratory, the frozen sample was taken out of the vial and placed in a petri dish containing filtered seawater. Using a needle and a binocular microscope under dim light, up to 30-40 appendicularians of each species were picked out as they detached from the thawing sample. Individuals were isolated onto a glass well slide with a drop of filtered seawater, photographed under an inverted microscope, and individually transferred to $300 \mu \mathrm{l}$ fluorometer minicells (Turner Designs) filled with $100 \mu \mathrm{l}$ of chilled $90 \%$ acetone. Samples were extracted for $24 \mathrm{~h}$ at $-20^{\circ} \mathrm{C}$ in darkness, and chlorophyll a equivalents concentration was measured using the standard fluorometric procedure, with a TD-700 fluorometer and a Minicell Adapter Kit (Turner Designs). The remaining unfrozen aliquot was then counted to determine appendicularian densities.

The digitised images of the appendicularians were used to determine the volume of food inside the gut of each individual, using specifically designed imageanalysis software (available on request from A. LópezUrrutia). Food parcels were visualized as dark shades inside the gut, and their length and area were measured. Their volume was calculated assuming the food parcel to be a prolate spheroid if it was material already packed in a faecal pellet. When 2 faecal pellets overlapped (in $<4 \%$ of the individuals measured), their area was measured collectively and then divided by 2 , to avoid overestimation of the total volume. When a food parcel was present in a stomach, its volume was also calculated using the formula for a prolate spheroid, but in the case of oikopleuriid species, where the stomach is dorso-ventrally flattened, the value obtained was divided by 3 to avoid overestimation of the actual volume (Bochdansky et al. 1998). The gut foodvolume content $\left(\mu \mathrm{m}^{3}\right.$ ind $\left.^{-1}\right)$ was calculated as the sum of the volumes of all food parcels in the gut. The trunk length $(\mathrm{TL}, \mu \mathrm{m})$ of each individual was measured as the distance between mouth and distal gonad end.

The vertical distribution of appendicularians was studied at Stn E2 from June 1999 to April 2000 with depth-specific tows using a $200 \mu \mathrm{m}$ WP-2 net and a Hydro-Bios net-release system. The depth intervals were selected according to the structure of the water column as revealed by the chlorophyll, salinity and temperature vertical profiles from the CTD cast. If a subsurface chlorophyll maximum was observed, then 3 depth intervals were used: surface layer (above the chlorophyll maximum), the chlorophyll maximum, and the deep layer (from $100 \mathrm{~m}$ to the base of the chlorophyll peak). When no subsurface chlorophyll maximum could be detected, only 2 depth intervals were used, and the surface-layer tow included the whole upper mixed layer, determined on the basis of the presence of a thermo- or halocline. Samples were processed and analysed for appendicularian species abundance as for the depth-integrated tows described above.

Data analyses. Multiple forward stepwise-regression analyses were completed separately for each species, and on both gut-chlorophyll and gut food-volume contents. The independent variables included trunk length, salinity and average temperature through the mixed layer, stratification index, concentration of ingestible particles (chlorophyll $<30 \mu \mathrm{m}$ and particle concentrations) and the concentration of chlorophyll in large non-ingestible $>30 \mu \mathrm{m}$ particles. All dependent and independent variables were logarithmically transformed to linearize the relationships and to stabilize variances. Possible spurious results because of multicolinearity among the independent variables were examined by looking for significant correlations among them, and by deleting 1 or more independent variables from the regression model and reanalysing the remaining data (Zar 1999).

ANCOVA was used to scale gut-content data for differences in body size between stations (Acuña et al. 1999). In essence, this method is based on the assumption that the stationwise slopes of the log to body-size to log gut-content regressions are equal (tests of parallelism were significant for all species indicating that this assumption was valid; data not shown), which 
allows for calculation of a stationwise intercept (i). The exponential of $i$, that is $10^{i}$, is equivalent to the gut content of an appendicularian $1 \mathrm{~mm}$ in trunk length. We prefer this method over the more traditional normalisation by body weight, because weight-specific rates are not entirely free from the effect of body size (Packard \& Boardman 1987, Dam \& Peterson 1991). Geometric mean regression (GMR: Ricker 1984) was used to obtain relationships that could be used to predict gut content from trunk length alone for each of the different species by pooling all data for each location and date.

Calculation of grazing rates. Individual ingestion rates (ng chlorophyll ind. ${ }^{-1} \mathrm{~d}^{-1}$ and $\mu \mathrm{m}^{3}$ ind..$^{-1} \mathrm{~d}^{-1}$ ) were calculated from gut-chlorophyll and gut-volume content measurements respectively in combination with gut-passage times (GPT) estimated from temperature $(T)$ and food concentration $(F C)$ using the equation:

$$
G P T=51.67 \mathrm{e}^{-0.0376 T} F C^{-0.245}
$$

developed by López-Urrutia \& Acuña (1999) for Oikopleura dioica. Food carbon concentrations required for this equation were estimated from chlorophyll concentrations in the $<30 \mu \mathrm{m}$ fraction after assuming that the phytoplankton carbon to chlorophyll (chl) ratio (phytoC:chl) for the $<30 \mu \mathrm{m}$ fraction was the same as the ratio for the total fraction. PhytoC:chl ratios for each station and date were obtained from total chlorophyll measurements and estimates of phytoplankton carbon based on microscopic counts. Phytoplankton carbon biomass was estimated from phytoplankton cell counts following the methods described in Holligan et al. (1984). The phytoC:chl ratios obtained at Stn E2 were used for Stns E1 and E3. Although the available food concentration would be higher if we used total particulate organic carbon instead of phytoplankton carbon, we took this conservative approach to keep our measurements of ingestion rate as underestimates. To calculate clearance rates, we divided the ingestion rates based on gut-chlorophyll contents by the concentration of ingestible chlorophyll in the water and the ingestion rates based on gut-volume contents by the particle concentrations. The percentage of the total chlorophyll and particle concentrations consumed by the appendicularian community on a daily basis was estimated by the combination of appendicularian abundances with individual ingestion rates ( $\mathrm{ng}$ chl ind..$^{-1} \mathrm{~d}^{-1}$ and $\mu \mathrm{m}^{3}$ ind. ${ }^{-1}$ $\mathrm{d}^{-1}$ respectively). The percentage of the PP consumed was calculated using ingestion rates at Stn E2 based on gut-chlorophyll measurements and the phytoC:chl ratios.

To calculate the proportion of autotrophic prey in the diet, gut contents measured by both techniques were transformed to carbon units. Gut chlorophyll contents were transformed using the phytoC:chl ratios obtained as described above. To convert gut-volume contents into carbon units we used total particulate organic carbon to volume ratios (POC:V) obtained from POC estimates and particle concentrations. At Stn L4, for each date sampled, POC measurements in the fraction $<30 \mu \mathrm{m}$ were obtained from triplicate $250 \mathrm{ml}$ aliquots taken at $10 \mathrm{~m}$ depth, filtered onto $25 \mathrm{~mm}$ GF/F filters and analysed using a Carlo-Erba Elemental Analyser Model NA 1500. In the Cantabrian Sea, POC concentrations were estimated from the chlorophyll $<30 \mu \mathrm{m}$ fraction using the relationships in Legendre \& Michaud (1999) (we applied their equation for locations where depth is $<300 \mathrm{~m}$ to Stns E1 and E2 and their equation for locations where depth $>300 \mathrm{~m}$ to Stn E3). POC:V ratios obtained by this indirect method were in the range of those obtained from direct measurement of POC at L4 and those reported by Holligan et al. (1984).

\section{RESULTS}

\section{Environments studied}

The locations studied (Fig. 1) ranged from Stn L4 (which is shallow, eutrophic and mixed during most of the year, with a strong spring diatom bloom: see Fig. 4B,C), through Stns E1 and E2 to Stn E3 (which is deep, seasonally stratified and with low chlorophyll concentrations except during the spring bloom: Fig. 4B,C). Although there may be differences because of geographical location (i.e. latitude) that are overlooked using our environmental descriptors, our intention was to cover a wide range of environments and not to sample a spatially consistent set of stations. In other words, we would have sampled more stations, in separate locations, if it would have been logistically possible. In general, salinity increased while stratification and particle concentration decreased from L4 through Stns E1 and E2 to E3 (Table 1, see Fig. 4).

\section{Appendicularian abundance}

At Stn E2, appendicularians were almost exclusively restricted to the upper surface mixed layer (Table 2, Fig. 2). Only in July 1999, were some Oikopleura longicauda and $O$. dioica individuals present in the subsurface chlorophyll maximum. The fact that appendicularians were generally present only in our surface samples led us to the preliminary conclusion that there could be a sampling bias because of our net-release system, and that appendicularians present in the nonsurface intervals were being under-sampled. If this was the reason, then the number of appendicularians collected by the depth-integrated sample from $100 \mathrm{~m}$ 
Table 1. Environmental variables, averaged over whole study period, at each location. Values in parentheses: range; no. of observations

\begin{tabular}{|c|c|c|c|c|c|c|}
\hline \multirow[t]{2}{*}{ Stn } & \multirow{2}{*}{$\begin{array}{c}\text { Particles } \\
2-30 \mu \mathrm{m} \\
\left(\mu \mathrm{m}^{3} \mathrm{ml}^{-1} \times 10^{6}\right)\end{array}$} & \multicolumn{2}{|c|}{ Chlorophyll ( $\left.\mu \mathrm{g} \mathrm{l}^{-1}\right)$} & \multirow{2}{*}{$\begin{array}{l}\text { Salinity } \\
\text { (psu) }\end{array}$} & \multicolumn{2}{|c|}{ Temperature $\left({ }^{\circ} \mathrm{C}\right)$} \\
\hline & & $0.7-30 \mu \mathrm{m}$ & $>30 \mu \mathrm{m}$ & & Mean & $\mathrm{SD}$ \\
\hline L4 & $\begin{array}{c}0.677 \\
(0.276-1.403 ; 35)\end{array}$ & $\begin{array}{c}1.06 \\
(0.03-2.89 ; 39)\end{array}$ & $\begin{array}{c}1.49 \\
(0.02-13.36 ; 39)\end{array}$ & $\begin{array}{c}34.61 \\
(33.42-42.86 ; 39)\end{array}$ & $\begin{array}{c}12.85 \\
(8.68-16.81 ; 39)\end{array}$ & $\begin{array}{c}0.33 \\
(0.01-1.21 ; 39)\end{array}$ \\
\hline E1 & $\begin{array}{c}0.49 \\
(0.19-1.52 ; 13)\end{array}$ & $\begin{array}{c}0.444 \\
(0.059-0.934 ; 13)\end{array}$ & $\begin{array}{c}0.30 \\
(0.01-2.06 ; 13)\end{array}$ & $\begin{array}{c}35.482 \\
(35.207-35.649 ; 13)\end{array}$ & $\begin{array}{c}14.67 \\
(12.05-19.06 ; 13)\end{array}$ & $\begin{array}{c}0.50 \\
(0.03-2.38 ; 13)\end{array}$ \\
\hline E2 & $\begin{array}{c}0.43 \\
(0.14-1.58 ; 13)\end{array}$ & $\begin{array}{c}0.455 \\
(0.054-0.882 ; 13)\end{array}$ & $\begin{array}{c}0.098 \\
(0.005-0.394 ; 13)\end{array}$ & $\begin{array}{c}35.531 \\
(35.333-35.643 ; 13)\end{array}$ & $\begin{array}{c}15.06 \\
(12.25-19.50 ; 13)\end{array}$ & $\begin{array}{c}0.69 \\
(0.01-2.83 ; 13)\end{array}$ \\
\hline E3 & $\begin{array}{c}0.281 \\
(0.146-0.373 ; 10)\end{array}$ & $\begin{array}{c}0.454 \\
(0.218-0.790 ; 10)\end{array}$ & $\begin{array}{c}0.21 \\
(0.02-1.31 ; 10)\end{array}$ & $\begin{array}{c}35.590 \\
(35.437-35.667 ; 10)\end{array}$ & $\begin{array}{c}15.09 \\
(12.26-19.74 ; 10)\end{array}$ & $\begin{array}{c}0.73 \\
(0.00-2.70 ; 10)\end{array}$ \\
\hline
\end{tabular}

to the surface should have been much higher than the number collected by the surface tow. This was not the case, and the appendicularian species abundances obtained in the depth-integrated sample were significantly correlated with abundances in the surface layer (Fig. 3). The slope of the log-log relationship was not significantly different from 1 ( $p=0.3$, Fig. 3), and the intercept was not significantly different from zero ( $p=0.09$, Fig. 3), indicating that there was not a sampling bias and confirming our result showing appendicularian populations concentrated in the upper surface layer. This result supports the selection of the $10 \mathrm{~m}$ depth sample (as opposed to a water-column average) to estimate food concentrations, and the use of the average temperature and salinity for the upper mixed layer as representative of the environment where appendicularians live.

Variation in appendicularian abundance was seasonal in the Cantabrian Sea, with higher values during spring and autumn (Fig. 4A). At Stn L4, abundances were lower throughout the year (Fig. 4A), except for an ephemeral peak of Oikopleura fusiformis in early autumn. On average, O. longicauda and O. fusiformis were the dominant species; $O$. dioica was the only species showing a clear coast-ocean trend, with higher densities near-shore (Table 3, Fig. 4). Fritillaria borealis and $F$. pellucida appeared in low abundances, mainly during early spring at Stns E1 and E2 (Table 3, Fig. 4).

\section{Gut content variability}

\section{Methodological considerations}

Ingestion rates estimated by the 2 gut-content techniques represent underestimates, since no correction was made for chlorophyll degradation or compression of food items when packed in faecal pellets. In addi- tion, our estimated gut-passage times ranged between 8.15 and $30 \mathrm{~min}$, with an average of $14.34 \mathrm{~min}$, well above previously reported values $(8 \mathrm{~min}$ for Oikopleura dioica: Alldredge 1981; $5.7 \mathrm{~min}$ for Fritillaria borealis: Á. López-Urrutia pers. obs.). Despite this conservative approach, which was intended to avoid overestimation of grazing impact, the clearance rates derived by combination of our ingestion rate estimates with ambient food concentrations were usually higher than the values reported in the literature (Fig. 5). Use of correction indices to account for pigment destruction (61 to $77 \%$ : Bochdansky et al. 1998) or material adhering to the filter house and not ingested (up to $80 \%$ of the material ingested: Acuña \& Kiefer 2000), would have led to unrealistically high clearance rates. Moreover, despite the completely different approaches that we have followed to measure gut content and food concentration (chlorophyll vs particle volume), both

Table 2. Oikopleura spp. and Fritillaria spp. Partitioning of abundance among the 3 depth strata at Stn E2, expressed as percentage of the total sum of abundances in all 3 depth intervals. Data are means (geometric-arithmetic) and standard deviation (between parentheses) of the percentages obtained for each sampling date. Geometric means were calculated through $\log _{10}+1$ transformation

\begin{tabular}{|lccc|}
\hline Species & Surface & $\begin{array}{c}\text { Chlorophyll } \\
\text { maximum }\end{array}$ & $\begin{array}{c}\text { Deep } \\
\text { layer }\end{array}$ \\
\hline O. longicauda & $75-87 \%$ & $3-23 \%$ & $1-3 \%$ \\
& $(33)$ & $(41)$ & $(6)$ \\
O. fusiformis & $98-98 \%$ & $1-4 \%$ & $0.2-0.41 \%$ \\
& $(4)$ & $(7)$ & $(1)$ \\
O. dioica & $46-83 \%$ & $9-50 \%$ & $0-0 \%$ \\
& $(41)$ & $(71)$ & $(0)$ \\
F. borealis & $100-100 \%$ & & 0 \\
& $(0)$ & & $(0)$ \\
F. pellucida & $91-92 \%$ & & $3-8 \%$ \\
& $(12)$ & & $(12)$ \\
\hline
\end{tabular}


methods yielded similar clearance rates (for $O$. dioica [Fig. 5], log-transformed clearance rates by both methods were significantly correlated, $\mathrm{r}^{2}=0.32, \mathrm{n}=325$, $\mathrm{p} \ll 0.001)$, confirming that appendicularians are nonselective filter-feeders and that our techniques for the measurement of grazing rates are mutually consistent. Only Alldredge (1981) measured clearance rates close to our estimates (Fig. 5). Since Alldredge's was the only previous in situ feeding study, this suggests that there is a mismatch between laboratory and field estimates, due to either improperly sampled food concentrations in field studies (e.g. food patchiness) or to underestimation of appendicularian ingestion rates due to stress in the laboratory.
Differences in gut contents between environments and season

The average gut contents are summarized in Table 3. There is a consistent pattern of lower gut-chlorophyll and gut-volume contents at the coastal (L4 and E1) compared to the oceanic (E2 and E3) stations. However, trunk lengths were also shorter at the coastal stations, thus lower gut contents near the coast could be simply due to the smaller size of appendicularians and not to fuller guts. To remove the effect of body size on gut contents, we calculated body size-corrected gut contents using ANCOVA. The corrected values showed a less pronounced pattern, although differ-

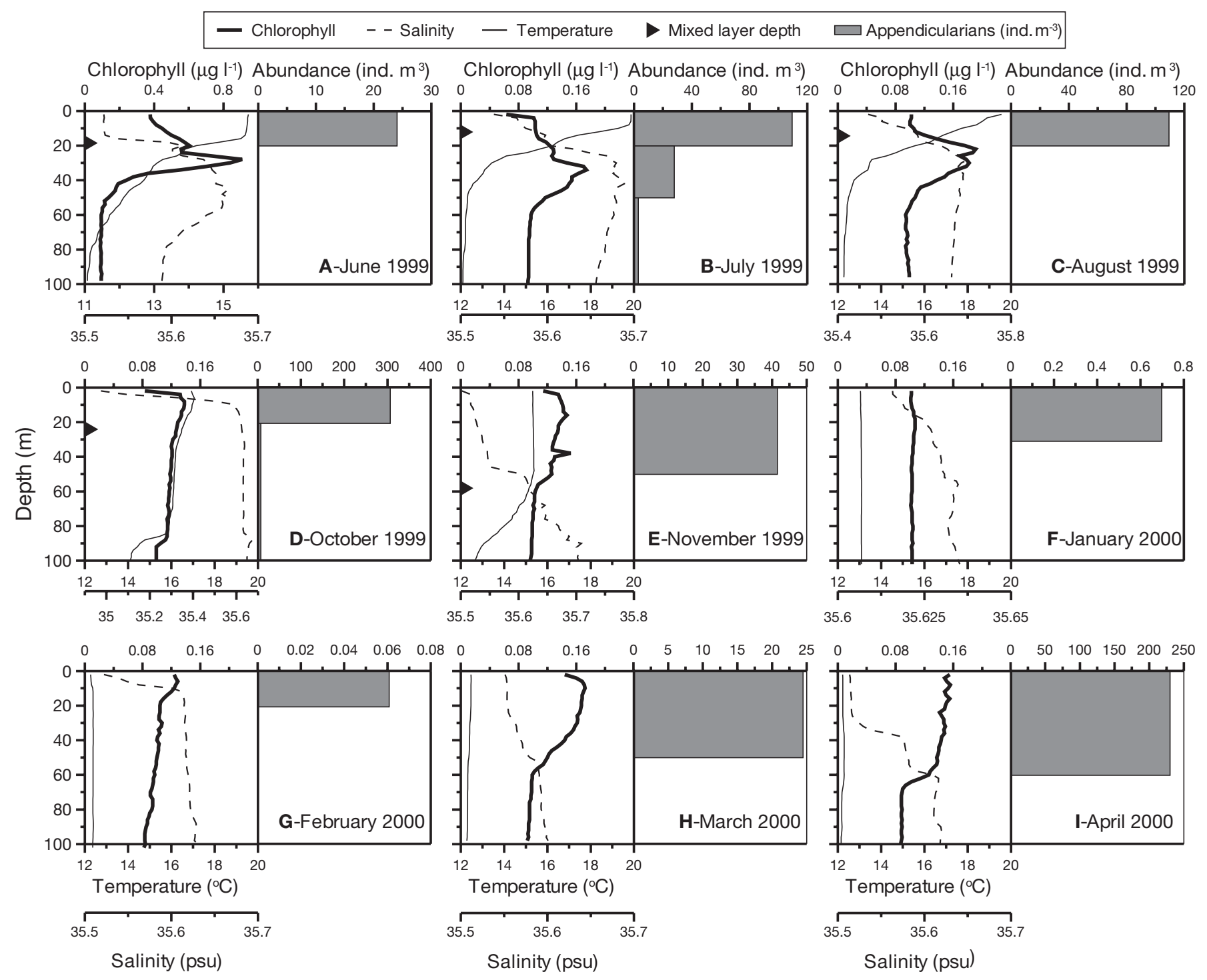

Fig. 2. Vertical distribution of appendicularians (combined data for all species at Stn E2). Left-hand panels show vertical profiles of chlorophyll, salinity and temperature from CTD cast. Arrowheads on depth axis indicate depth of mixed layer. Note different scales on upper and lower abscissas 
ences between shallow and oceanic locations still remained, indicating environmental effects that could not be explained by animal size. Amongst the different species, Oikopleura longicauda and O. fusiformis had the higher gut contents, particularly when the effect of trunk length was removed. There was no clear seasonal pattern at any of the locations in either gutchlorophyll contents or gut food-volume contents, especially when compared to the differences between stations (Fig. 4), and when taking into account the seasonal changes in body size (Fig. 4D).

\section{Multivariate analysis}

Particle concentration was excluded from the multiple regression analysis, because when it showed significant effects (only 2 out of the 10 models, data not shown) it was significantly correlated with the rest of the independent variables, leading to spurious results. In addition, measurements of particle concentration are rarely available in oceanographic studies, restricting the potential use by other investigators of the predictive equations obtained. Body size was the variable explaining most of the variability (Table 4) followed by salinity, which is consistent with the trend from less saline coastal environments with low gut contents to more saline, oceanic stations where gut contents were higher (cf. Tables 1 \& 2). Gut contents increased with increasing food concentration $\left(\mathrm{chl}_{<30}\right.$ : Table 4$)$ and decreased with increasing concentration of large, non-ingestible particles $\left(\mathrm{chl}_{>30}\right.$ : Table 4). The effect of temperature was small and not significant for any species. However, gut contents showed a decreasing pattern with increasing stratification index $\left(T_{\mathrm{SD}}\right.$ : Table 4$)$.

The high number of degrees of freedom in our multiple regression analysis (Table 4) imply that we were able to detect and include in our regression models statistically weak effects. However, the predictive power of the variables responsible for those weak effects was low (Table 4; Graham 2001). Also, because it was not possible to collect the same the number of appendicularians for gut-content analyses at all the different locations or dates, the patterns depicted by the multipleregression analysis are less influenced by the situations where appendicularians were rare and the number of individuals analysed lower, than by those stations where a sufficient number of individuals was collected for gut-content measurement. To correct for this bias we performed the same multiple-regression approach, but instead of the raw data we used the average gut-content values at each location once the differences in body size had been corrected through ANCOVA. Therefore, a corrected or adjusted mean

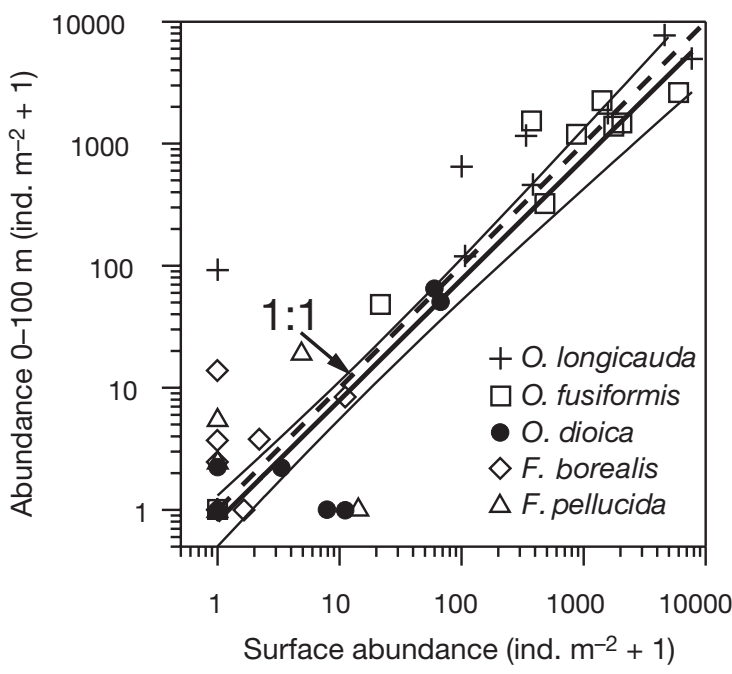

Fig. 3. Oikopleura spp. and Fritillaria spp. Relationship between total number of individuals for each species collected in vertical tows from bottom $(100 \mathrm{~m})$ to surface and in tows through surface layer only (see Fig. 2 for depth ranges). Dashed line: values where all individuals collected are in the surface layer (1:1 ratio). Thick continuous line: geometric mean regression relationship does not depart significantly from 1:1 (intercept $=-0.09 \pm 0.1 \mathrm{SE}$ : Student's $t$-test for $H_{0}$ intercept $=0, t_{43}=1.73, \mathrm{p}=0.09 ;$ slope $=0.989 \pm 0.055 \mathrm{SE}$ : Student's $t$-test for $H_{0}$, slope $=1, t_{43}=1.05, \mathrm{p}=0.3$ ). Thin continuous lines: $95 \% \mathrm{CI}$ for regression estimates

was obtained for each station and date, which can be interpreted as the gut content of a standard individual $1 \mathrm{~mm}$ in trunk length. Through this approach we also reduced the number of data points (and hence the degrees of freedom), which implies that only those variables that have a strong statistical effect on the appendicularian gut contents can be detected as significant. Only 2 significant relationships could be detected by the forward stepwise multiple-regression approach: the gut-chlorophyll contents of Oikopleura longicauda increased with increasing salinity (Fig. 6A) and the gut-chlorophyll contents of $O$. fusiformis decreased with increasing chlorophyll concentration in the large-particle fraction (Fig. 6B).

We estimated simplified regression equations that used only the variable explaining most of the variability (i.e. trunk length). GMR power curves relating gut content and trunk length were highly significant and had exponents ranging from 3.32 to 5.15 for gut volume (Fig. 7A-E) and between 2.45 and 3.01 for gutpigment content (Fig. 7F-J). The higher allometric exponents for gut-volume than for gut-chlorophyll contents (Fig. 7, Table 4) mean that larger individuals eat less autotrophic prey per unit volume ingested than small individuals. Our estimates show that ca. $60 \%$ of the gut contents of most species are of heterotrophic origin, with the exception of Fritillaria borealis, whose 
Table 3. Oikopleura spp. and Fritillaria spp. Statistics averaged over whole study period, for each species and location. Data are means \pm SD (no. of observations; for abundance: no. of dates sampled - no. of dates when species was present). To remove the effect of differing trunk length among the different locations, body size-corrected gut contents (representing average gut content of a standard individual $1 \mathrm{~mm}$ long obtained by ANCOVA: see 'Materials and methods') are shown. equiv.: equivalents

\begin{tabular}{|c|c|c|c|c|c|c|c|c|c|c|}
\hline $\begin{array}{l}\text { Parameter } \\
\text { Stn }\end{array}$ & \multicolumn{2}{|c|}{ O. longicauda } & \multicolumn{2}{|c|}{ O. fusiformis } & \multicolumn{2}{|c|}{ O. dioica } & \multicolumn{2}{|c|}{ F. borealis } & \multicolumn{2}{|c|}{ F. pellucida } \\
\hline \multicolumn{11}{|c|}{ Abundance (ind. $\mathrm{m}^{-2}$ ) } \\
\hline L4 & $359 \pm 878$ & $(37-18)$ & $416 \pm 1552$ & $(37-14)$ & $879 \pm 960$ & $(37-34)$ & $106 \pm 193$ & $(37-19)$ & 0 & $(37-0)$ \\
\hline E1 & $3826 \pm 5174$ & $(13-12)$ & $2265 \pm 3219$ & $(13-11)$ & $165 \pm 456$ & $(13-12)$ & $431 \pm 1544$ & $(13-5)$ & $443 \pm 1588$ & $(13-3)$ \\
\hline E2 & $2960 \pm 3020$ & $(13-12)$ & $2413 \pm 2717$ & $(13-11)$ & $124 \pm 407$ & $(13-8)$ & $810 \pm 2023$ & (13-9) & $8 \pm 21$ & $(13-4)$ \\
\hline E3 & $5313 \pm 6819$ & $(10-9)$ & $2809 \pm 3827$ & $(10-9)$ & $9 \pm 17$ & $(10-5)$ & $13 \pm 27$ & $(10-7)$ & $2 \pm 4$ & $(10-4)$ \\
\hline \multicolumn{11}{|c|}{ Trunk length $(\mu \mathrm{m})$} \\
\hline L4 & $570 \pm 187$ & $(84)$ & $640 \pm 132$ & $(67)$ & $614 \pm 188$ & $(271)$ & $699 \pm 83$ & (5) & & \\
\hline E1 & $539 \pm 196$ & (86) & $625 \pm 173$ & (30) & $619 \pm 215$ & $(76)$ & $710 \pm 183$ & (15) & $920 \pm 146$ & (18) \\
\hline E2 & $590 \pm 224$ & (131) & $792 \pm 153$ & (85) & $574 \pm 206$ & (34) & $659 \pm 169$ & (23) & $1171 \pm 324$ & (42) \\
\hline E3 & $770 \pm 287$ & (91) & $778 \pm 199$ & (51) & $620 \pm 254$ & (10) & $628 \pm 167$ & $(42)$ & $1172 \pm 245$ & (11) \\
\hline \multicolumn{11}{|c|}{ Gut chlorophyll content (ng chl a equiv. ind. ${ }^{-1}$ ) } \\
\hline L4 & $0.474 \pm 0.356$ & $(84)$ & $0.441 \pm 0.279$ & $(67)$ & $0.469 \pm 0.333$ & $3(271)$ & $0.359 \pm 0.172$ & (5) & & \\
\hline E1 & $0.800 \pm 0.587$ & (85) & $0.738 \pm 0.527$ & (30) & $0.660 \pm 0.527$ & $7 \quad 76)$ & $0.243 \pm 0.121$ & (15) & $0.50 \pm 0.39$ & (18) \\
\hline E2 & $1.31 \pm 1.13$ & (129) & $1.46 \pm 1.01$ & (83) & $0.693 \pm 0.561$ & 1 (34) & $0.371 \pm 0.228$ & (23) & $1.02 \pm 0.69$ ) & (42) \\
\hline E3 & $1.807 \pm 1.594)$ & $(74)$ & $1.50 \pm 1.45$ & $(32)$ & $0.73 \pm 0.70$ & $(10)$ & $0.412 \pm 0.254$ & $(42)$ & $1.90 \pm 1.43)$ & (11) \\
\hline \multicolumn{11}{|c|}{ Body size-corrected gut chlorophyll content (ng chl a equiv. ind..$^{-1}$ ) } \\
\hline $\mathrm{L} 4$ & $1.310 \pm 0.769$ & $(84)$ & $0.890 \pm 0.577$ & $(67)$ & $1.048 \pm 0.548$ & $3(271)$ & $0.547 \pm 0.191$ & (5) & & \\
\hline E1 & $2.35 \pm 1.57$ & $(85)$ & $1.53 \pm 0.96$ & (30) & $1.47 \pm 0.96$ & $(76)$ & $0.397 \pm 0.202$ & $(15)$ & $0.64 \pm 0.80$ & (18) \\
\hline $\mathrm{E} 2$ & $3.04 \pm 2.01$ & (129) & $2.12 \pm 1.44$ & (83) & $1.82 \pm 1.22$ & $(34)$ & $0.660 \pm 0.466$ & $(23)$ & $0.83 \pm 0.46$ & $(42)$ \\
\hline E3 & $2.82 \pm 1.84$ & $(74)$ & $2.06 \pm 1.67$ & (32) & $1.73 \pm 1.10$ & (10) & $0.737 \pm 0.348$ & $(42)$ & $1.36 \pm 0.73$ & (11) \\
\hline \multicolumn{11}{|c|}{ Gut food-volume $\left(10^{4} \mu^{3}\right.$ ind. $\left.^{-1}\right)$} \\
\hline L4 & $72.7 \pm 68.1$ & $(84)$ & $41.1 \pm 41.1$ & $(67)$ & $69.0 \pm 81.0$ & $(271)$ & $15.5 \pm 10.2$ & (5) & & \\
\hline E1 & $91 \pm 121$ & $(86)$ & $84 \pm 103$ & $(30)$ & $115 \pm 122$ & $(76)$ & $10.9 \pm 8.2$ & $(15)$ & $77 \pm 89$ & $(18)$ \\
\hline $\mathrm{E} 2$ & $113 \pm 137$ & $(131)$ & $116 \pm 113$ & $(85)$ & $83 \pm 126$ & $(34)$ & $6.76 \pm 4.27$ & $(23)$ & $410 \pm 477$ & $(42)$ \\
\hline E3 & $239 \pm 255$ & $(91)$ & $112 \pm 120$ & (51) & $122 \pm 149$ & $(10)$ & $9.2 \pm 8.6$ & $(42)$ & $319 \pm 276$ & (11) \\
\hline \multicolumn{11}{|c|}{ Body size-corrected gut food-volume $\left(10^{-4} \mu^{3}\right.$ ind. $\left.^{-1}\right)$} \\
\hline $\mathrm{L} 4$ & $314 \pm 196$ & $(84)$ & $133 \pm 97$ & $(67)$ & $215 \pm 177$ & $(271)$ & $32.1 \pm 17.3$ & (5) & & \\
\hline E1 & $319 \pm 213$ & $(86)$ & $271 \pm 213$ & $(30)$ & $324 \pm 218$ & $(76)$ & $21.0 \pm 11.5$ & (15) & $119.6 \pm 125.0$ & (18) \\
\hline E2 & $373 \pm 255$ & (131) & $219 \pm 192$ & (85) & $293 \pm 206$ & (34) & $16.6 \pm 8.9$ & (23) & $144.4 \pm 112.1$ & (42) \\
\hline E3 & $364 \pm 230$ & (91) & $198 \pm 144$ & (51) & $312 \pm 243$ & (10) & $23.9 \pm 12.5$ & $(42)$ & $145.2 \pm 72.6$ & (11) \\
\hline
\end{tabular}

diet was more strongly dominated by autotrophic prey (Table 5). The calculation of the proportion that the autotrophic prey comprises of the total ingested carbon depends strongly on the conversion factors used to transform data from chlorophyll and volume units to carbon values. Differences between stations might reflect the different methodologies used to obtain the particulate carbon concentrations (direct measurement at Stn L4 and conversion from chlorophyll using the equations in Legendre \& Michaud 1999 at Stns E1 to E3). To understand the implications of this difference, we have recalculated POC values at Stn L4 using the formula in Legendre \& Michaud (1999). The percentage autotrophic prey obtained using this formula differ by less than $6 \%$ from those obtained using the real POC measurements and the correlation between both estimates is highly significant $\left(\mathrm{r}^{2}=0.97, F_{1,50}=1800\right.$, $\mathrm{p} \ll 0.001$ ), and not significantly different from a $1: 1$ relationship (i.e. the slope was not significantly different from $1, t_{1,50}=2.35 ; \mathrm{p} \ll 0.001$, and the intercept was not significantly different from zero $t_{1,50}=18.58 ; \mathrm{p}=$ 0.023). We therefore consider that the impact of this difference in the measurement of POC between stations is minimal.

\section{Grazing impact on natural particles}

Grazing impact of the appendicularian community on phytoplankton biomass was highest at the oceanic stations during early spring and autumn, with maximum values close to $10 \%$ of the total biomass removed daily (Table 5, Fig. 8). These values do not take into account material cleared but not ingested (i.e. attached to the filter house). Oikopleura longicauda and O. fusiformis were the most important particle grazers (Table 5).

The appendicularian community at Stn E2 consumed over $40 \%$ of the PP per day during autumn, when PP was low and appendicularians were abundant 


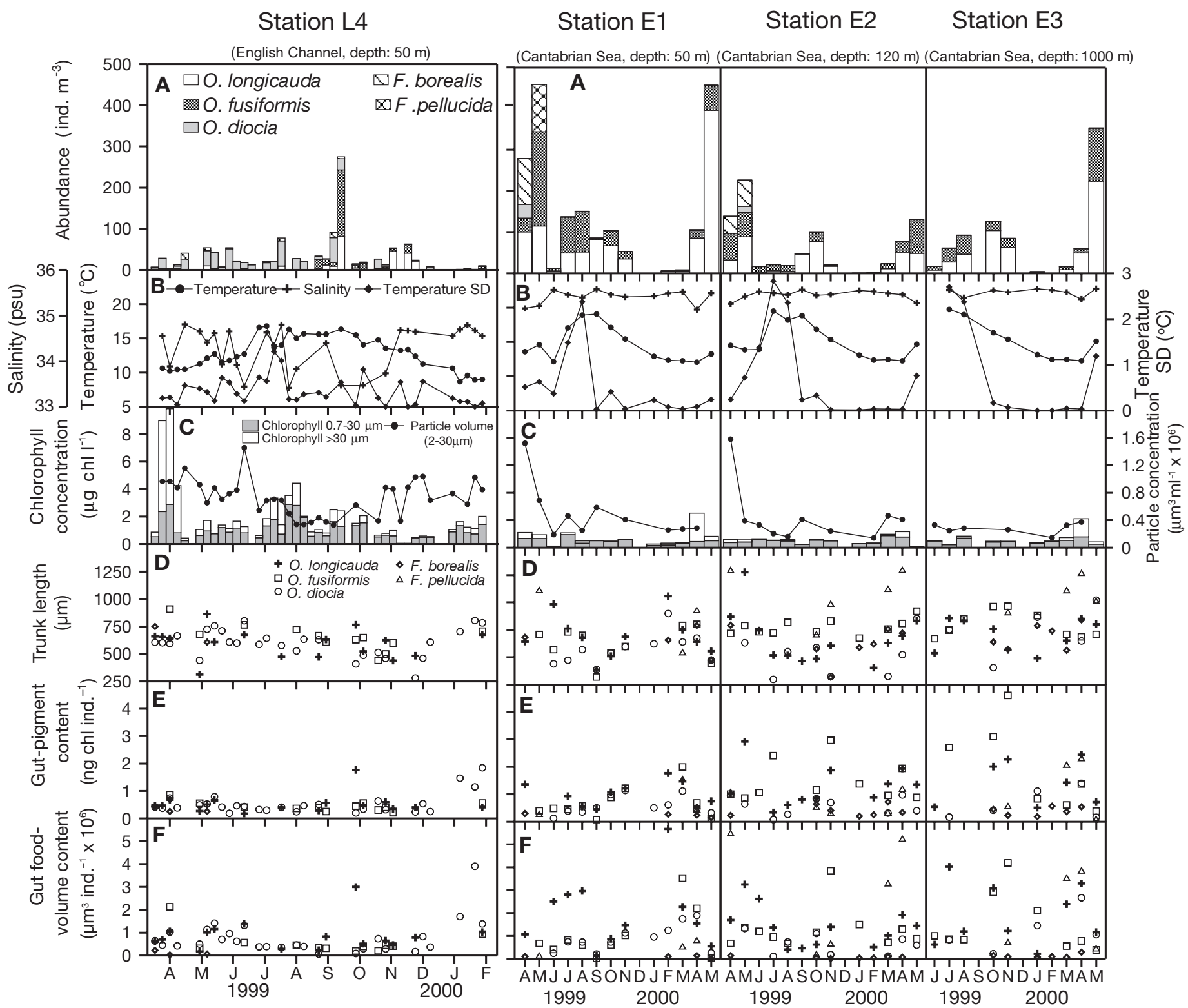

Fig. 4. Oikopleura spp. and Fritillaria spp. Seasonal variation in (A) species densities, (B) salinity and temperature (averaged for mixed layer) and stratification index (standard deviation of temperature in upper $50 \mathrm{~m}$ of water column), (C) size-fractioned chlorophyll and particle concentrations, (D) average trunk length, (E) average gut-chlorophyll content, and (F) average gut foodvolume content for appendicularians at each station studied

(Fig. 9A). During the spring bloom, appendicularians consumed 3 to $40 \%$, and on a yearly basis removed an average $8 \%$ (geometric mean) of the daily PP. In order to compare our results with previous reports of in situ appendicularian grazing impact, we compiled data from publications reporting simultaneous estimates of appendicularian-community ingestion rates and PP (Fig. 9B). According to this compilation, appendicularian community ingestion rate increases with increasing productivity, although the percentage of the PP removed by appendicularians decreased with the increasing productivity. The percentage of the PP consumed averaged $8 \pm 26 \%$ (geometric mean $\pm \mathrm{SE}$ ) in unproductive ( $\mathrm{PP}<250 \mathrm{mgC} \mathrm{m}^{-2} \mathrm{~d}^{-1}$, sensu Calbet $2001), 4.6 \pm 2.5$ in moderately productive $(250<\mathrm{PP}<$ $1000 \mathrm{mg} \mathrm{C} \mathrm{m}^{-2} \mathrm{~d}^{-1}$ ), and $1.52 \pm 1.4$ in highly productive ( $\mathrm{PP}>1000 \mathrm{mg} \mathrm{C} \mathrm{m}^{-2} \mathrm{~d}^{-1}$ ) ecosystems.

The exponent of the least-squares power relationship between appendicularian community ingestion rate and PP was significantly lower than 1 (Fig. 9B, exponent $\pm \mathrm{SE}=0.64 \pm 0.16$, constant $\pm \mathrm{SE}=0.37 \pm$ 0.34 , Student's $t$-test for $H_{0}$ : exponent $=1, \mathrm{p}=0.01$ ), 


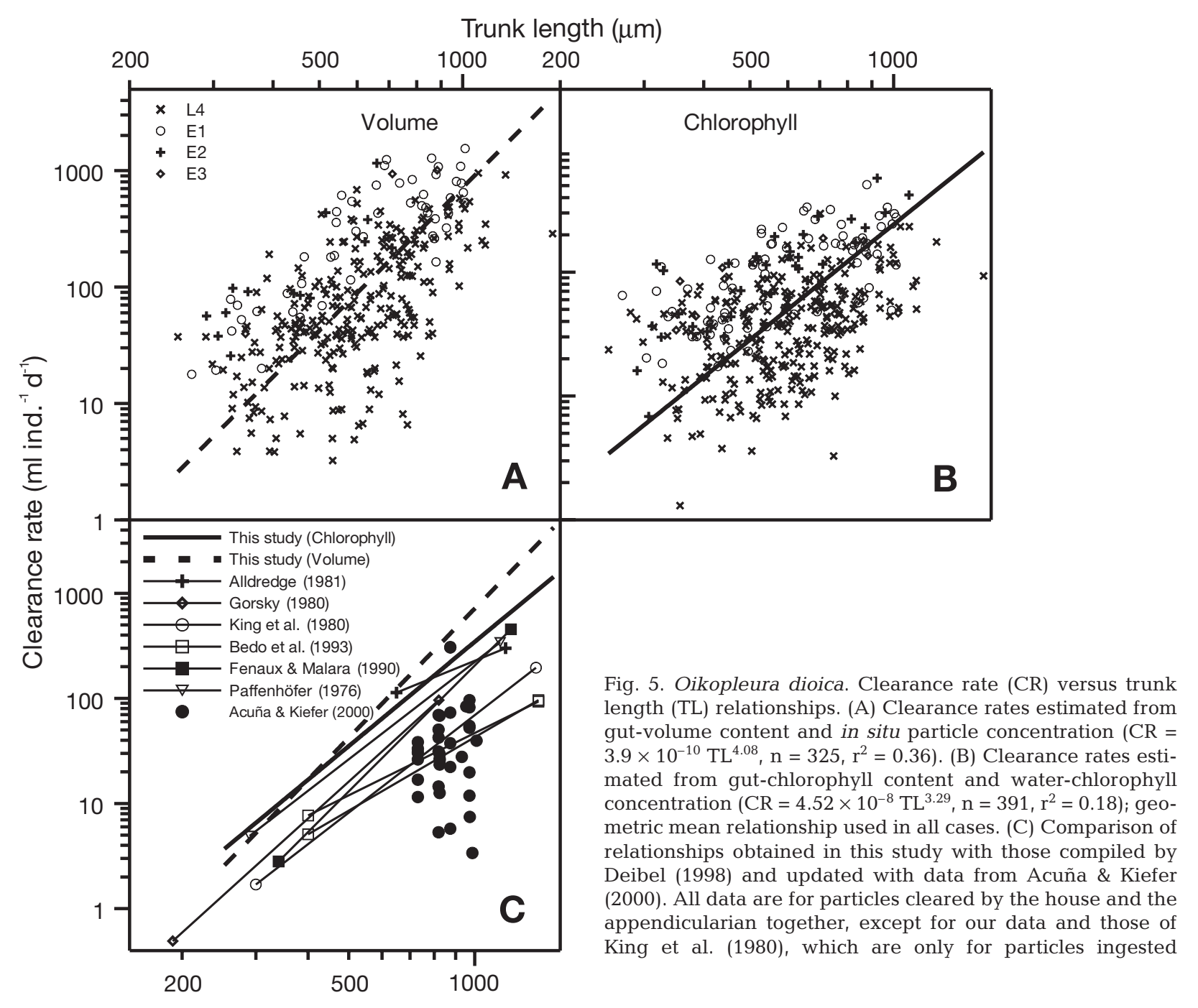

also suggesting that the relative impact (the percentage of PP grazed) was lower in more productive situations. This pattern is strikingly similar to that reported by Calbet (2001) in a recent review of total mesozooplankton grazing impact on PP (Fig. 9B). The exponent of the relationship between total mesozooplankton ingestion rate and PP obtained by Calbet (2001) was $0.64 \pm 0.082$ (exponent $\pm \mathrm{SE}$ ), and the constant was $1.03 \mathrm{mg} \mathrm{C} \mathrm{m}^{-2} \mathrm{~d}^{-1}$ (his Fig. 1A). Although these equations should be used with caution, since the unexplained variance is high, the fact that both regressions have an almost identical slope indicates that both total mesozooplankton and appendicularian ingestion rates increase at the same rate with increasing $\mathrm{PP}$, or else, that the relative contribution of appendicularian ingestion rates to total zooplankton ingestion rates remains constant. The ratio appendicularian grazing to total mesozooplankton grazing can be calculated if we divide the intercept of the appendicularian ingestion to PP relationship (0.37) by the intercept obtained by Calbet (2001) for total mesozooplankton
(1.03). This calculation indicates that the appendicularian ingestion rate represents $36 \%$ of the total mesozooplankton ingestion, irrespective of the primary productivity.

\section{DISCUSSION}

\section{What controls feeding rates of appendicularians?}

The variable explaining most of the variance in gut contents was appendicularian size (Fig. 7, Table 4). Once the effect of body size was removed, the amount of variability explained by the other variables was relatively small (Table 4). If a balance between complexity of the model and predictive power is to be achieved, body size should be the independent variable of choice (Table 4, Fig. 7), as is the case for copepods (Morales et al. 1990) and cold-water appendicularians (Deibel 1988). It should also be taken into account that the maximum variance in gut contents that can be ex- 
Table 4. Oikopleura spp. and Fritillaria spp. Summary of multiple forward stepwise regression models with gut chlorophyll content (GCC, ng chl) and gut food-volume content $\left(\mathrm{GVC}, \mu \mathrm{m}^{3}\right.$ ind. $\left.{ }^{-1}\right)$ as dependent variables and trunk length (TL, $\left.\mu \mathrm{m}\right)$, chlorophyll concentration for each size fraction $\left(\mathrm{chl}_{<30}, \mathrm{chl}_{>30}, \mu \mathrm{g} \mathrm{chl}\right.$ a equiv. $\left.\mathrm{l}^{-1}\right)$, average mixed layer salinity $(\mathrm{S}$, psu) and temperature $\left(T,{ }^{\circ} \mathrm{C}\right)$, and stratification index (temperature standard deviation of upper $50 \mathrm{~m}$ of water column $T_{\mathrm{SD}}{ }^{\circ} \mathrm{C}$ ) as independent variables. Only those descriptors with significant partial correlation are shown. ${ }^{*}$ Significant, ${ }^{* *}$ highly significant. ${ }^{a, b, c, d i n d i c a t e ~ t h e ~ o r d e r ~}$ each descriptor entered the multiple regression model

\begin{tabular}{|c|c|c|c|c|c|c|c|c|}
\hline Parameter & $\mathrm{b}$ & $\mathrm{SE}$ & $t$ & $\begin{array}{c}\mathrm{R}^{2} \\
\text { increase }\end{array}$ & $\mathrm{b}$ & SE & $t$ & $\begin{array}{c}\mathrm{R}^{2} \\
\text { increase }\end{array}$ \\
\hline O. longicauda & \multicolumn{4}{|c|}{$\begin{array}{c}\mathbf{G C C}=\mathbf{1 0}^{-36.6} \mathbf{T L}^{\mathbf{1 . 6 7 9}} \mathbf{S}^{\mathbf{2 0 . 5}} \mathbf{T}_{\mathbf{S D}}{ }^{-\mathbf{0 . 1 4 7}} \mathbf{c h l}_{>\mathbf{3 0}}{ }^{-\mathbf{0 . 0 1 1}} \\
\left(F_{3,332}=133.3, \mathrm{R}^{2}=0.56\right)\end{array}$} & \multicolumn{4}{|c|}{$\begin{array}{c}\mathbf{G V C}=\mathbf{1 0} \mathbf{0}^{-\mathbf{2 . 0 4}} \mathbf{T L}^{\mathbf{2 . 8 1}} \mathbf{T}_{\mathbf{S D}}{ }^{-\mathbf{0 . 0 8 7}} \\
\left(F_{2,353}=398.08, \mathrm{R}^{2}=0.69\right)\end{array}$} \\
\hline Intercept & -36.6 & \pm 4.7 & $-7.84^{* *}$ & & -2.04 & \pm 0.28 & $-7.32^{* *}$ & \\
\hline $\mathrm{TL}(\mu \mathrm{m})$ & 1.679 & \pm 0.098 & $17.21^{* * a}$ & 0.42 & 2.810 & \pm 0.100 & $28.20^{* * a}$ & 0.68 \\
\hline $\mathrm{S}$ (psu) & 20.5 & \pm 3.0 & $6.77^{* * b}$ & 0.08 & & & & \\
\hline $\begin{array}{l}T_{\mathrm{SD}}\left({ }^{\circ} \mathrm{C}\right) \\
\mathrm{chl}_{>30}\left(\mu g \mathrm{l}^{-1}\right)\end{array}$ & $\begin{array}{l}-0.147 \\
-0.011\end{array}$ & $\begin{array}{l} \pm 0.027 \\
\pm 0.023\end{array}$ & $\begin{array}{l}-5.35^{* * \mathrm{c}} \\
-3.34^{* \mathrm{~d}}\end{array}$ & $\begin{array}{l}0.04 \\
0.01\end{array}$ & -0.087 & \pm 0.027 & $-3.17^{* * b}$ & 0.01 \\
\hline O. fusiformis & \multicolumn{4}{|c|}{$\begin{array}{c}\mathbf{G C C}=\mathbf{1 0} 0^{-23.4} \mathbf{T L}^{1.99} \mathbf{S}^{11.36} \mathbf{c h l}_{<30}{ }^{\mathbf{0 . 4 1}} \mathbf{c h l}_{>30^{-0.22}} \\
\left(F_{4,184}=37.13, \mathrm{R}^{2}=0.45\right)\end{array}$} & \multicolumn{4}{|c|}{$\begin{array}{c}\mathbf{G V C}=\mathbf{1 0}^{-\mathbf{3 . 1}} \mathbf{T L}^{\mathbf{3 . 0 4}} \mathbf{c h l}_{<\mathbf{3 0}}{ }^{\mathbf{0 . 1 8 3}} \mathbf{c h l}_{>30}{ }^{-\mathbf{0 . 2 1}} \mathbf{T}_{\mathbf{S D}}{ }^{-\mathbf{0 . 0 7 8}} \\
\left(F_{4,198}=46.52, \mathrm{R}^{2}=0.48\right)\end{array}$} \\
\hline Intercept & -23.4 & \pm 4.3 & $-5.48^{* *}$ & & -3.10 & \pm 0.68 & $-4.59^{* *}$ & \\
\hline $\mathrm{TL}(\mu \mathrm{m})$ & 1.99 & \pm 0.22 & $9.18^{* * a}$ & 0.27 & 3.04 & \pm 0.24 & $12.81^{* * a}$ & 0.43 \\
\hline $\mathrm{S}(\mathrm{psu})$ & 11.36 & \pm 2.82 & $4.03^{* * b}$ & 0.06 & & & & \\
\hline $\operatorname{chl}_{<30}\left(\mu \mathrm{gl} \mathrm{l}^{-1}\right)$ & 0.415 & \pm 0.075 & $5.57^{* * c}$ & 0.05 & 0.183 & \pm 0.085 & $2.15^{* \mathrm{~d}}$ & 0.01 \\
\hline $\operatorname{chl}_{>30}\left(\mu g \mathrm{l}^{-1}\right)$ & -0.220 & \pm 0.048 & $-4.62^{* * \mathrm{~d}}$ & 0.06 & -0.210 & \pm 0.053 & $-3.96^{* * b}$ & 0.03 \\
\hline$T_{\mathrm{SD}}\left({ }^{\circ} \mathrm{C}\right)$ & & & & & -0.078 & \pm 0.032 & $-2.41^{* \mathrm{c}}$ & 0.02 \\
\hline O. dioica & \multicolumn{4}{|c|}{$\begin{aligned} \mathbf{G C C}= & \mathbf{1 0}^{-4.13} \mathbf{T L}^{1.29} \mathbf{c h l}_{\mathbf{3 0}{ }^{-0.08}} \mathbf{T}_{\mathbf{S D}}{ }^{-0.20} \\
& \left(F_{3,337}=82.97, \mathrm{R}^{2}=0.42\right)\end{aligned}$} & \multicolumn{4}{|c|}{$\begin{array}{c}\mathbf{G V C}=\mathbf{1 0}^{-5.79} \mathbf{T L}^{2.38} \mathbf{T}_{\mathrm{SD}}{ }^{-\mathbf{0 . 2 3 3}} \mathbf{c h l}_{<\mathbf{3 0}}{ }^{-\mathbf{0 . 1 5 9}} \mathbf{S}^{-4.47} \\
\left(F_{4,336}=93.99, \mathrm{R}^{2}=0.53\right)\end{array}$} \\
\hline Intercept & -4.13 & \pm 0.27 & $-15.29^{* *}$ & & 5.79 & \pm 1.45 & $3.98^{* *}$ & \\
\hline $\mathrm{TL}(\mu \mathrm{m})$ & 1.291 & \pm 0.097 & $13.26^{* * a}$ & 0.31 & 2.38 & \pm 0.14 & $17.31^{* * a}$ & 0.43 \\
\hline$T_{\mathrm{SD}}\left({ }^{\circ} \mathrm{C}\right)$ & -0.198 & \pm 0.028 & $-7.11^{* * \mathrm{~b}}$ & 0.10 & -0.233 & \pm 0.039 & $-5.90^{* * b}$ & 0.05 \\
\hline $\begin{array}{l}\mathrm{chl}_{>30}\left(\mu g \mathrm{l}^{-1}\right) \\
\mathrm{S}(\mathrm{psu})\end{array}$ & -0.077 & \pm 0.021 & $-3.57^{* * \mathrm{c}}$ & 0.02 & -4.47 & \pm 0.91 & $-4.89^{* * \mathrm{c}}$ & 0.03 \\
\hline F. borealis & \multicolumn{4}{|c|}{$\begin{aligned} \mathbf{G C C}= & \mathbf{1 0}^{-3.85} \mathbf{T L}^{\mathbf{1 . 2}} \mathbf{c h l}_{>30^{-0.25}} \mathbf{c h l}_{<30} \mathbf{0 . 6 6} \\
& \left(F_{3,78}=10.93, \mathrm{R}^{2}=0.30\right)\end{aligned}$} & \multicolumn{4}{|c|}{$\begin{array}{c}\mathbf{G V C}=\mathbf{1 0}^{-\mathbf{2 . 5 4}} \mathbf{T L}^{\mathbf{2 . 6 1}} \\
\left(F_{1,80}=86.23, \mathrm{R}^{2}=0.52\right)\end{array}$} \\
\hline Intercept & -3.85 & \pm 0.69 & $-5.56^{* *}$ & & -2.54 & \pm 0.79 & $-3.22^{*}$ & \\
\hline $\mathrm{TL}(\mu \mathrm{m})$ & 1.20 & \pm 0.25 & $4.88^{* * \mathrm{a}}$ & 0.13 & 2.61 & \pm 0.28 & $9.29^{* * a}$ & 0.52 \\
\hline $\mathrm{chl}_{>30}\left(\mu \mathrm{g} \mathrm{l}^{-1}\right)$ & -0.253 & \pm 0.060 & $-4.19^{* * b}$ & 0.08 & & & & \\
\hline $\operatorname{chl}_{<30}\left(\mu \mathrm{g} \mathrm{l}^{-1}\right)$ & 0.66 & \pm 0.21 & $3.19^{* * \mathrm{c}}$ & 0.09 & & & & \\
\hline F. pellucida & \multicolumn{4}{|c|}{$\begin{array}{c}\mathbf{G C C}=\mathbf{1 0}^{-\mathbf{9 2}} \mathbf{T L}^{\mathbf{1 . 2 1}} \mathbf{S}^{\mathbf{5 7}} \\
\left(F_{2,68}=13.60, \mathrm{R}^{2}=0.28\right)\end{array}$} & \multicolumn{4}{|c|}{$\begin{array}{c}\mathbf{G V C}=\mathbf{1 0}^{-5.41} \mathbf{T L}^{3.63} \mathbf{T}_{\mathbf{S D}^{-0.44}} \\
\left(F_{2,68}=139.62, \mathrm{R}^{2}=0.80\right)\end{array}$} \\
\hline Intercept & -92 & \pm 35 & $-2.65^{*}$ & & -5.41 & \pm 0.95 & $-5.68^{* *}$ & \\
\hline $\mathrm{TL}(\mu \mathrm{m})$ & 1.21 & \pm 0.32 & $3.81^{* * a}$ & 0.21 & 3.63 & \pm 0.34 & $10.80^{* * a}$ & 0.75 \\
\hline $\mathrm{S}$ (psu) & 57 & \pm 23 & $2.52^{* b}$ & 0.07 & & & & \\
\hline$T_{\mathrm{SD}}\left({ }^{\circ} \mathrm{C}\right)$ & & & & & -0.44 & \pm 0.10 & $-4.34^{* * b}$ & 0.05 \\
\hline
\end{tabular}

plained by regression on environmental variables or body size is limited by the existence of an intrinsic natural variability in the gut contents due to the mechanism of digestion in appendicularians (López-Urrutia \& Acuña 1999) and therefore the real explained variance on the estimated ingestion rates should be much higher.

In explanatory power, body size was followed by salinity; this is consistent with the observed trend of increasing gut content from coastal to oceanic stations (Tables 3 $\& 4$ ). Sato et al. (2001) found an inverse relationship between house production and salinity under laboratory conditions. Although there is little information on the direct effect of salinity on feeding rates, this could suggest that the euryhaline distribution of some appendicularians species may be achieved at the cost of metabolic performance. Temperature was a poor predictor of gut contents (Table 4), although gut contents were inversely related to an index of thermal stratification (Table 4).

We detected an inverse relationship between the concentration of large non-ingestible particles in the water and appendicularian gut-chlorophyll contents $\left(\mathrm{chl}_{>30}\right.$, Table 4$)$. A similar pattern has previously been reported for cold-water appendicularians by Acuña et al. (1999), who suggested that large particles could clog the inlet filter present in the house of some appendicularian species and therefore inhibit their ingestion 


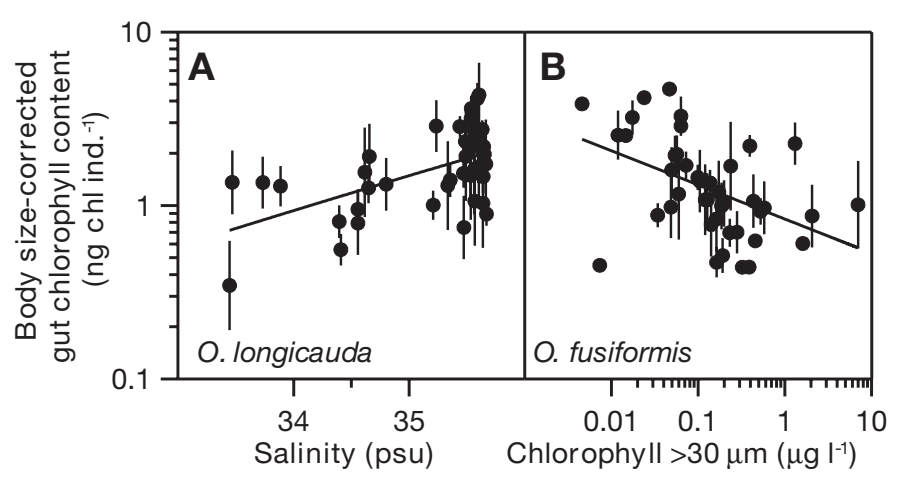

Fig. 6. Oikopleura longicauda and O. fusiformis. Average, body size-corrected (to standard trunk length of $1 \mathrm{~mm}$ using ANCOVA) gut-chlorophyll contents (SGCC) as a function of (A) salinity (S) and (B) chlorophyll content of particles larger than $30 \mu \mathrm{m}\left(\mathrm{chl}_{>30}\right)$. Lines represent least-squares power regressions $\left(\mathrm{SGCC}=2.91 \times 10^{-25} \mathrm{~S}^{16}, \mathrm{r}^{2}=0.3, F_{1,41}=17.47\right.$, $\mathrm{p}<0.001$ for $O$. longicauda; $\mathrm{SGCC}=0.84 \mathrm{chl}_{>30}{ }^{-0.2}, \mathrm{r}^{2}=0.19$, $F_{1,35}=8.36, \mathrm{p}<0.007$ for $O$. fusiformis)

rates. Sato et al. (2001) reported higher houseproduction rates when large phytoplankton cells were offered to Oikopleura dioica in the laboratory. This would result in a higher proportion of individuals expanding a new filter house (and hence not feeding) in appendicularian populations exposed to high concentrations of large phytoplankton. The fact that gutchlorophyll contents of O. longicauda, which lacks an inlet filter (Alldredge 1977), were also lower when large particle concentrations were high (Table 4), suggests that inlet filter clogging is not the reason for that pattern. Also, it should be noted that the correlation between gut-chlorophyll contents and large, noningestible particles was significant in 3 out of the 5 species studied, but was significant in only in 1 when considering gut-volume content (Table 4). This suggests that relatively more non-autotrophic prey is ingested during periods of high concentrations of large particles, and that the decrease in gut-chlorophyll contents could be a consequence of a change in diet rather than a clogging effect. Whether this increase in nonautotrophic prey is due to feeding on diatom exudates or on higher bacterial concentrations fuelled by phytoplankton exudates during bloom conditions (Sanders \& Purdie 1998) needs further investigation.

Gut-pigment contents in copepods usually increase by up to 1 order of magnitude during phytoplankton blooms (e.g. Dam \& Peterson 1991, Irigoien et al. 1998). We did not observe such an increase in the gut contents of appendicularians during our seasonal study, and the correlation between food concentration and gut contents was generally low and not significant (Table 4). Acuña \& Kiefer (2000) studied the functional response of Oikopleura dioica under laboratory conditions, and estimated half-saturation constants of 38, 177 and $290 \mu \mathrm{g} \mathrm{Cl}^{-1}$ (for the 3 phytoplankton species they used as a food source). Such high concentrations were rarely encountered in our

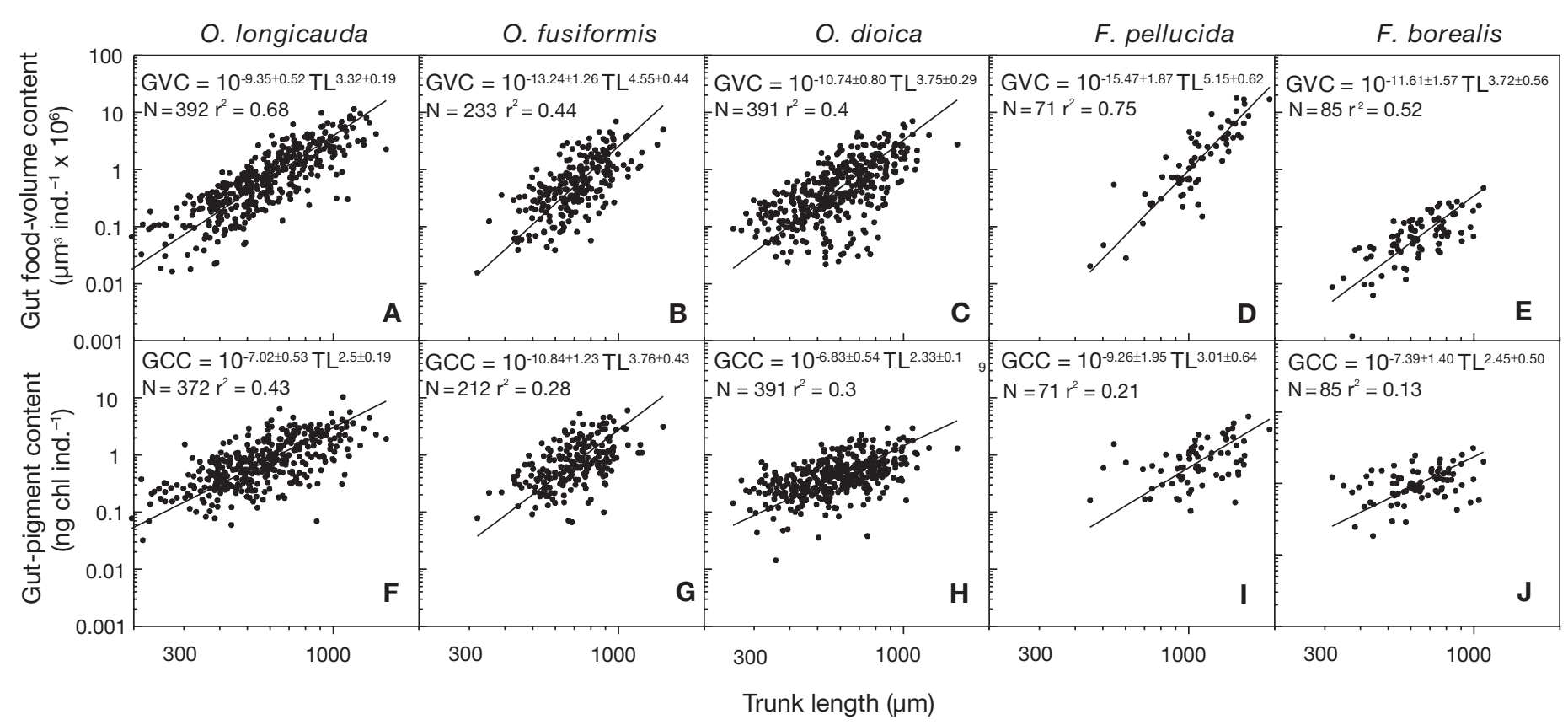

Fig. 7. Oikopleura spp. and Fritillaria spp. (A-E) Gut food-volume content (GVC); (F-J) gut-chlorophyll content (GCC) as a function of appendicularian trunk length (TL). Relationships were obtained by pooling data from all locations and dates and calculating geometric mean relationship on the $\log _{10}$-transformed data. Equations show parameter estimates $\pm 95 \%$ confidence limits, sample size and $\mathrm{r}^{2}$ values 
Table 5. Oikopleura spp. and Fritillaria spp. Average grazing impact as percentage chlorophyll and volume consumed on a daily basis. Data are geometric (GM, through $\log _{10}+1$ transformation) and arithmetic means, standard deviation (SD) and maximum for each location. Percentage chlorophyll-containing prey represents that proportion of total ingested material from autotrophic prey after transformation of gut-content volume to total carbon, and gut chlorophyll to phytoplanktonic carbon (see 'Materials and methods' for details)

\begin{tabular}{|c|c|c|c|c|c|c|c|c|c|c|c|}
\hline \multirow{2}{*}{$\begin{array}{c}\text { Species } \\
\text { Stn }\end{array}$} & \multicolumn{4}{|c|}{ Chlorophyll } & \multicolumn{4}{|c|}{ Volume } & \multicolumn{3}{|c|}{ \% chlorophyll-containing prey } \\
\hline & GM & Mean & $\mathrm{SD}$ & Max. & GM & Mean & $\mathrm{SD}$ & Max. & GM & Mean & $\mathrm{SD}$ \\
\hline \multicolumn{12}{|l|}{ O. longicauda } \\
\hline L4 & 0.0158 & 0.0164 & \pm 0.0361 & 0.1450 & 0.078 & 0.092 & \pm 0.204 & 0.682 & 8.0 & 16.2 & \pm 23.5 \\
\hline E1 & 0.72 & 0.92 & \pm 1.09 & 3.77 & 1.43 & 2.03 & \pm 2.42 & 7.63 & 10 & 29 & \pm 45 \\
\hline E2 & 0.81 & 1.25 & \pm 1.79 & 5.04 & 0.76 & 1.33 & \pm 2.51 & 8.25 & 14.4 & 22.9 & \pm 16.8 \\
\hline E3 & 0.94 & 1.51 & \pm 1.94 & 4.65 & 1.49 & 2.00 & \pm 1.71 & 4.00 & 15 & 21 & \pm 17 \\
\hline All stations & 0.35 & 0.60 & \pm 1.25 & 5.04 & 0.51 & 0.89 & \pm 1.75 & 8.25 & 9 & 21 & \pm 11 \\
\hline \multicolumn{12}{|l|}{ O. fusiformis } \\
\hline L4 & 0.01 & $<0.01$ & & 0.0553 & 0.0216 & 0.0226 & \pm 0.0458 & 0.1939 & 9.6 & 17.1 & \pm 19.3 \\
\hline E1 & 0.31 & 0.38 & \pm 0.50 & 1.43 & 0.74 & 1.01 & \pm 1.19 & 2.93 & 13 & 27 & \pm 32 \\
\hline E2 & 0.52 & 0.80 & \pm 1.48 & 5.33 & 0.51 & 0.60 & \pm 0.66 & 2.31 & 15.3 & 31.1 & \pm 48.7 \\
\hline E3 & 0.72 & 0.97 & \pm 1.12 & 2.81 & 0.70 & 1.00 & \pm 1.36 & 3.59 & 19 & 20 & \pm 10 \\
\hline All stations & 0.21 & 0.33 & \pm 0.83 & 5.33 & 0.27 & 0.41 & \pm 0.82 & 3.59 & 11 & 23 & \pm 13 \\
\hline \multicolumn{12}{|l|}{ O. dioica } \\
\hline L4 & $<0.01$ & 0.052 & \pm 0.064 & 0.249 & 0.159 & 0.176 & \pm 0.224 & 0.880 & 12.1 & 31.6 & \pm 59.3 \\
\hline E1 & 0.01 & $<0.01$ & & 0.0397 & 0.039 & 0.041 & \pm 0.070 & 0.209 & 8 & 12 & \pm 16 \\
\hline $\mathrm{E} 2$ & 0.014 & 0.016 & \pm 0.051 & 0.185 & 0.042 & 0.052 & \pm 0.168 & 0.560 & 9 & 14 & \pm 11 \\
\hline E3 & $<0.01$ & $<0.01$ & & 0.005 & $<0.01$ & $<0.01$ & & 0.0194 & 3 & 5 & \pm 5 \\
\hline All stations & 0.03 & 0.03 & \pm 0.05 & 0.25 & 0.09 & 0.10 & \pm 0.19 & 0.88 & 9 & 24 & \pm 10 \\
\hline \multicolumn{12}{|l|}{ F. borealis } \\
\hline L4 & $<0.01$ & $<0.01$ & & 0.02 & 0.00 & $<0.01$ & & 0.004 & 40 & 42 & \pm 16 \\
\hline E1 & 0.02 & 0.03 & \pm 0.10 & 0.37 & 0.01 & 0.01 & \pm 0.03 & 0.09 & 60 & 125 & \pm 155 \\
\hline $\mathrm{E} 2$ & 0.013 & 0.014 & \pm 0.048 & 0.174 & 0.00 & $<0.01$ & & 0.04 & 102 & 139 & \pm 121 \\
\hline E3 & $<0.01$ & $<0.01$ & & 0.00 & 0.00 & $<0.01$ & & 0.002 & 53 & 72 & \pm 56 \\
\hline All stations & 0.01 & 0.01 & \pm 0.05 & 0.37 & 0.00 & $<0.01$ & & 0.09 & 59 & 103 & \pm 66 \\
\hline \multicolumn{12}{|l|}{ F. pellucida } \\
\hline L4 & 0 & 0 & & 0.00 & 0 & 0 & & 0.00 & & & \\
\hline E1 & 0.03 & 0.04 & \pm 0.13 & 0.4607 & 0.02 & 0.03 & \pm 0.09 & 0.3239 & 18 & 33 & \pm 36 \\
\hline $\mathrm{E} 2$ & $<0.01$ & $<0.01$ & & 0.0073 & 0.01 & 0.01 & \pm 0.03 & 0.0906 & 6 & 8 & \pm 7 \\
\hline E3 & $<0.01$ & $<0.01$ & & 0.0023 & $<0.01$ & $<0.01$ & & 0.0094 & 6.9 & 7.2 & \pm 2.2 \\
\hline All stations & 0.01 & 0.01 & \pm 0.06 & 0.46 & 0.01 & 0.01 & \pm 0.04 & 0.32 & 7 & 15 & \pm 9 \\
\hline \multicolumn{12}{|l|}{ All species } \\
\hline $\mathrm{L} 4$ & 0.082 & 0.084 & \pm 0.070 & 0.265 & 0.29 & 0.32 & \pm 0.26 & 0.94 & 10.0 & 24.5 & \pm 10.7 \\
\hline E1 & 0.96 & 1.20 & \pm 1.15 & 3.87 & 1.95 & 2.82 & \pm 3.19 & 10.54 & 10 & 34 & \pm 13 \\
\hline $\mathrm{E} 2$ & 1.14 & 1.92 & \pm 2.96 & 10.12 & 1.23 & $\begin{array}{l}2.02 \\
2.00\end{array}$ & \pm 3.31 & 11.11 & 10 & 40 & \pm 17 \\
\hline E3 & 1.34 & 2.21 & \pm 2.56 & 6.13 & 2.08 & 3.00 & \pm 2.64 & 6.52 & 20 & 28 & \pm 15 \\
\hline All stations & 0.58 & 1.01 & \pm 1.90 & 10.12 & 0.91 & 1.50 & \pm 2.46 & 11.11 & 11 & 31 & \pm 53 \\
\hline
\end{tabular}

study (Fig. 4C, Table 1), indicating that the conditions were non-saturating and that we should expect higher gut contents with increasing food concentrations - in contrast to what we have actually found. This suggests that food concentration is not an appropriate predictor of appendicularian gut contents when the spatio-temporal coverage of the study is large. Nevertheless, during shorter periods or in localized areas where variability due to other factors should be smaller, food concentration could be significantly correlated with ingestion and therefore used as a predictor variable (e.g. Acuña et al. 2002).

An alternative hypothesis would be that appendicularians were not food-limited during our study (see
López-Urrutia et al. 2003, this issue) and that the seasonal increase in appendicularian population densities was related to changes in the physical conditions or a decrease in predatory pressure. This hypothesis is supported by the lack of relationship between appendicularian densities and gut contents (Fig. 4) and by the vertical distribution of appendicularian populations, which does not follow the depth distribution of their phytoplanktonic prey (Fig. 2). The association of appendicularians with surface layers has previously been reported by Shiga (1985), who considered Oikopleura longicauda, O. fusiformis, O. dioica and Fritillaria borealis as 'surface dwellers'. Fenaux et al. (1998) have also shown that the upper mixed layer contains numerous 


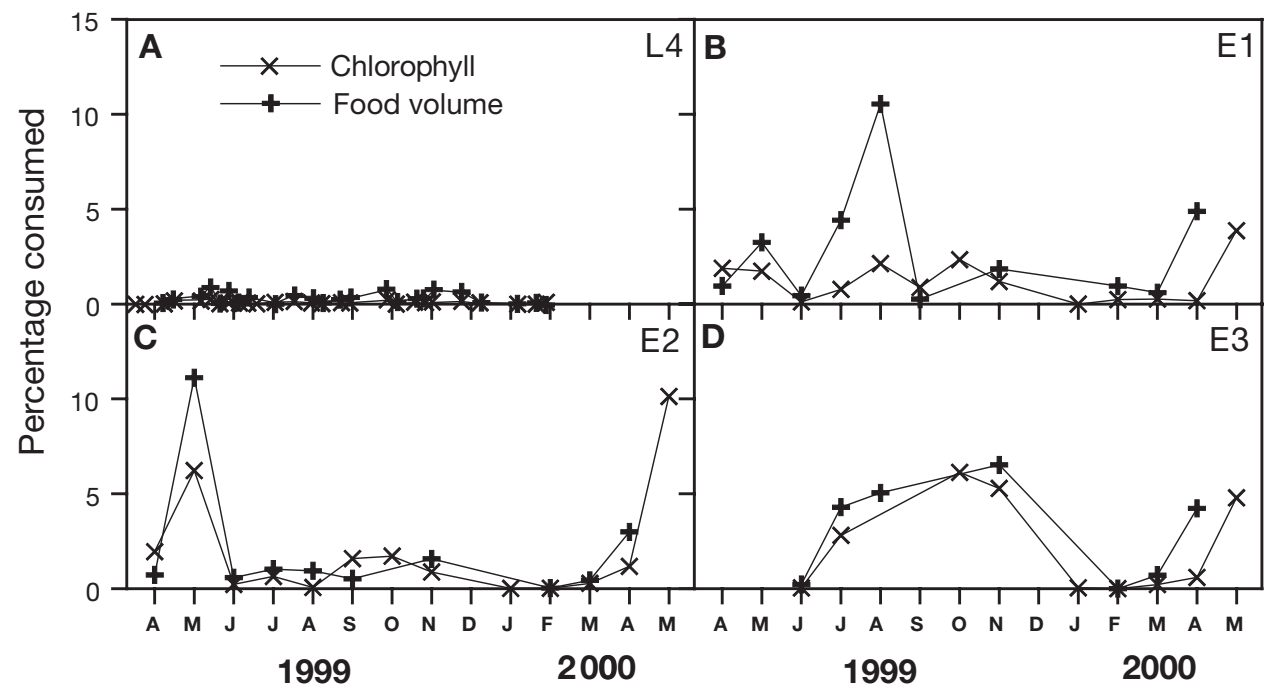

Fig. 8. Seasonal variation in percentage of total chlorophyll concentration and particle concentration in the size range 2 to $30 \mu \mathrm{m}$ consumed by the appendicularian community on a daily basis, estimated by gut-chlorophyll and gut food-volume techniques respectively at each station

individuals of relatively few species whereas mid-depth waters contain less abundant but more diverse communities. Longhurst et al. (1984) and Ashjian et al. (1997) found that cold-water appendicularians exist preferentially in surface waters. The mechanism responsible for this vertical distribution (and for departures from this generalized pattern: see Deibel 1988, Acuña 1994, and O. labradoriensis in Shiga 1985) is unknown, and our knowledge of appendicularian ecology is still too limited to determine whether it is a response to the physical environment, to the tendency for upward swimming when the animals abandon their filter houses (Alldredge 1982,
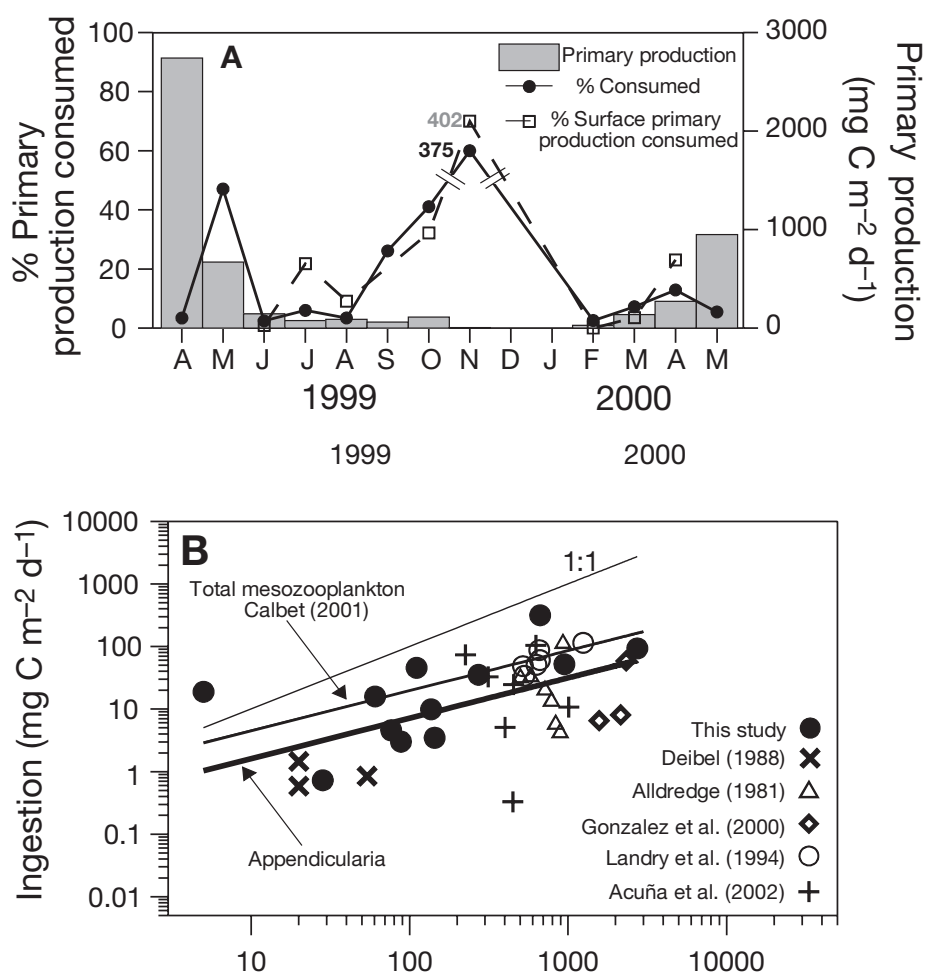

Primary production $\left(\mathrm{mg} \mathrm{C} \mathrm{m}^{-2} \mathrm{~d}^{-1}\right)$
Fig. 9. (A) Seasonal variation in primary production integrated over the whole photic layer and percentage of primary production (PP) removed by appendicularian community on a daily basis estimated from gut-pigment contents and appendicularian abundance (see 'Materials and methods'); dashed lines and squares: estimates obtained using abundance data from surface depth intervals (see Fig. 2) and PP integrated only for the surface layer sampled during the appendicularian tows. (B) Compilation of simultaneous measurements of ingestion rates $\left(I_{\text {app }}, \mathrm{mg} \mathrm{C} \mathrm{m}^{-2} \mathrm{~d}^{-1}\right)$ and $\mathrm{PP}\left(\mathrm{mg} \mathrm{C} \mathrm{m}^{-2} \mathrm{~d}^{-1}\right)$ of the appendicularian community. Data from this study are values measured at Stn E2 integrated over the whole water column. Ingestion rates in Gonzalez et al. (2000) were recalculated using their gut-chlorophyll content data uncorrected for pigment degradation, and gut-passage times estimated using equation in López-Urrutia \& Acuña (1999). PP given by Alldredge (1981) was estimated from rates of increase and concentrations of ingestible particulate organic carbon $(<15 \mu \mathrm{m})$, assuming a water-column depth of $30 \mathrm{~m}$ (A. Alldredge pers. comm.). Ingestion rates measured by Deibel (1988) represent daily consumption of ingestible chlorophyll $(<70 \mu \mathrm{m})$. Thick line: leastsquares power regression $\left(I_{\text {app }}=0.37 \mathrm{PP}^{0.64} ; F_{1,69}=\right.$ $\left.17 ; \mathrm{p}=0.002 ; \mathrm{r}^{2}=0.32 ; \mathrm{N}=38\right)$; thin line: relationship between total mesozooplankton ingestion and pp from Calbet (2001); top line: values for which ingestion equals PP (1:1) 
and Á. Lopez-Urrutia pers. obs. on cultured organisms) or a mechanism to avoid predation or competition.

Our study has considered the most abundant appendicularian species in European temperate waters (Fenaux et al. 1998), whose trophic ecology remained unexplored in most cases. The equations in Table 4 \& Fig. 6 (legend) in combination with estimates of gutpassage time (López-Urrutia \& Acuña 1999) should therefore provide a tool to predict ingestion rates of phytoplankton and total particle material by the most significant constituents of the appendicularian community in European waters.

\section{Impact of appendicularians on phytoplankton and suspended particulate matter}

During our study, the proportion of phytoplankton standing stock removed daily by the appendicularian community was generally low (1 to $3 \%$ : Table 5, Fig. 8), and close to average values reported for copepods in similar environments (Bautista \& Harris 1992, Barquero et al. 1998). Appendicularian grazing impact on total particulate material was usually higher than on autotrophic prey (Table 5, Fig. 8), probably because our Coulter Counter measurements underestimated the actual food concentration by not taking into account the bacterial size fraction, which also contributes to the appendicularian diet (King 1982). Since bacteria are included in our gut volume but not in our Coulter Counter measurements, which only covered the 2 to $30 \mu \mathrm{m}$ size fraction, the proportion of total particulate material grazed by appendicularians is overestimated by our method. Moreover, our result showing that non-autotrophic material represents over $60 \%$ of the ingested material for most species (Table 5) stresses the need to further investigate the role of heterotrophic organisms and detritus in the trophic ecology of appendicularians. Gerber \& Marshall (1974) reported that $89 \%$ of the gut contents of Oikopleura longicauda were composed of detritus, and Dagg et al. (1996) have shown that $O$. dioica is able to feed on finegrained lithogenic material from river discharge. Except for the possible overestimation of the grazing rates on total particulate material explained above, our grazing rates should be considered as underestimates, since we did not take into account any possible pigment degradation in the guts or undigested material adhering to the filter house. We also failed to determine the contribution of early juveniles and smallbodied fritillariid species with trunk lengths smaller than 300 to $500 \mu \mathrm{m}$, which were probably not properly sampled using a $200 \mu \mathrm{m}$ net (Fenaux \& Palazzoli 1979).

Calbet (2001) found that the total mesozooplankton ingestion rate increased as a power function of PP, but that the relative grazing pressure declined with increasing productivity. Our results suggest that appendicularian ingestion rates exhibit a strikingly similar relationship to PP and that they account for a constant proportion of the total mesozooplankton ingestion rates and, therefore, grazing pressure, irrespective of primary productivity (Fig. 9B). This relationship supports the traditional view that the grazing impact of appendicularians is higher in oligotrophic ecosystems (Gorsky \& Fenaux 1998). However, when Calbet (2001) restricted his analysis to studies considering only copepods, the relationship between ingestion rates and PP was not significant; therefore, we could speculate that copepods are even more important grazers than appendicularians under oligotrophic conditions, since the population ingestion rates of appendicularians decrease with decreasing productivity (Fig. 9B) while copepod ingestion rates remain unchanged. The considerable proportion of the total mesozooplankton grazing that could be attributable to appendicularians (Fig. 9B) and the high percentage of PP removed during unproductive periods (Fig. 9A) suggest that their importance in marine ecosystems should not be neglected if we seek an unbiased global view of the role of mesozooplankton as grazers of PP.

Acknowledgements. We are indebted to M. López and T. Smith for their help in sorting appendicularians, and to L. Viesca and D. Harbour for the phytoplankton carbon biomass estimates. N. Gonzalez and L. Viesca provided the PP measurements, and B. Head the POC data at Stn L4. B. Obermüller, A. Isla, S. Ceballos, D. Fernandez, M. Kiefer and crew members of the 'Jose Rioja', 'Sepia' and 'Squilla' provided assistance. This study was a joint collaboration between the University of Oviedo and Plymouth Marine Laboratory under the EURAPP (MAS3-CT98-0161) project. Sampling in the Cantabrian Sea was conducted under contract 'Control a largo plazo de las condiciones químico-biológicas en la plataforma continental asturiana' between the Instituto Español de Oceanografía (L. Valdés) and the University of Oviedo (R. Anadón). The timeseries data at Stn L4 were obtained under the NERC 'Marine Productivity' thematic programme. This study was partly funded by the United Kingdom Natural Environment Research Council through the Plymouth Marine Laboratory core strategic research programme 'Microbially Driven Biogeochemical Cycles' (MDB). This is MDB contribution no. 112. We are grateful to A. Calbet, A. Hirst, P. Tiselius, L. Valdés, R. Anadón and 3 anonymous reviewers for their useful comments on an earlier version of this manuscript.

\section{LITERATURE CITED}

Acuña JL (1994) Summer vertical distribution of appendicularians in the central Cantabrian Sea (Bay of Biscay). J Mar Biol Assoc UK 74:585-601

Acuña JL, Kiefer M (2000) Feeding functional response of the appendicularian Oikopleura dioica. Limnol Oceanogr 45: 608-618

Acuña JL, Deibel D, Bochdansky AB, Hatfield E (1999) In situ 
ingestion rates of appendicularian tunicates in the northeast water polynya (NE Greenland). Mar Ecol Prog Ser 186:149-160

Acuña JL, Deibel D, Saunders PA, Booth B, Hatfield E, Klein B, Mei ZP, Rivkin R (2002) Phytoplankton ingestion by appendicularians in the North Water. Deep-Sea Res Part II Top Stud Oceanogr 49:5101-5115

Aiken J, Bellan I (1990) Optical oceanography: an assessment of a towed method. In: Herring PJ, Campbell AK, Whitfield M, Maddock L (eds) Light and life in the sea. Cambridge University Press, Cambridge, p 39-57

Alldredge AL (1977) House morphology and mechanisms of feeding in the Oikopleuridae. J Zool 181:175-188

Alldredge AL (1981) The impact of appendicularian grazing on natural food concentrations in situ. Limnol Oceanogr 26:247-257

Alldredge AL (1982) Aggregation of spawning appendicularians in surface windrows. Bull Mar Sci 32:250-254

Ashjian C, Smith S, Bignami F, Hopkins T, Lane P (1997) Distribution of zooplankton in the northeast water polynya during summer 1992. J Mar Syst 10:279-298

Båmstedt U, Gifford DJ, Irigoien X, Atkinson A, Roman M (2000) Feeding. In: Harris RP, Wiebe PH, Lenz J, Skjoldal HR, Huntley M (eds) ICES zooplankton methodology manual. Academic Press, London, p 297-399

Barquero S, Cabal JA, Anadón R, Fernández E, Varela M, Bode A (1998) Ingestion rates of phytoplankton by copepod size fractions on a bloom associated with an off-shore front off NW Spain. J Plankton Res 20:957-972

Bautista B, Harris RP (1992) Copepod gut contents, ingestion rates and grazing impact on phytoplankton in relation to size structure of zooplankton and phytoplankton during a spring bloom. Mar Ecol Prog Ser 82:41-50

Bedo AW, Acuña JL, Robins D, Harris RP (1993) Grazing in the micron and the sub-micron particle size range: the case of Oikopleura dioica (Appendicularia). Bull Mar Sci 53:2-14

Bochdansky AB, Deibel D (1999) Functional feeding response and behavioural ecology of Oikopleura vanhoeffeni (Appendicularia, Tunicata). J Exp Mar Biol Ecol 233:181-211

Bochdansky AB, Deibel D, Hatfield EA (1998) Chlorophyll a conversion and gut passage time for the pelagic tunicate Oikopleura vanhoeffeni (Appendicularia). J Plankton Res 20:2179-2197

Bone Q (1998) The biology of pelagic tunicates. Oxford University Press, Oxford

Calbet A (2001) Mesozooplankton grazing effect on primary production: a global comparative analysis in marine ecosystems. Limnol Oceanogr 46:1824-1830

Cushing DH (1989) A difference in structure between ecosystems in strongly stratified waters and in those that are only weakly stratified. J Plankton Res 11:1-13

Dagg MJ, Green EP, McKee BA, Ortner PB (1996) Biological removal of fine-grained lithogenic particles from a large river plume. J Mar Res 54:149-160

Dam HG, Peterson WT (1991) In situ feeding behaviour of the copepod Temora longicornis: effects of seasonal changes in chlorophyll size fractions and female size. Mar Ecol Prog Ser 71:113-123

Deibel D (1988) Filter feeding by Oikopleura vanhoeffeni: grazing impact on suspended particles in cold ocean waters. Mar Biol 99:177-186

Deibel D (1998) Feeding and metabolism of Appendicularia. In: Bone Q (ed) The biology of pelagic tunicates. Oxford University Press, Oxford, p 139-149

Fenaux R, Malara G (1990) Taux de filtration de l'áppendiculaire Oikopleura dioica. Rapp P-V Réun Comm Int Mer Méditerr 32:224
Fenaux R, Palazzoli I (1979) Estimation in situ d'une population d'Oikopleura longicauda (Appendicularia) à l'aide de deux filets de maille différente. Mar Biol 55:197-200 (in French with English Abstract)

Fenaux R, Bone Q, Deibel D (1998) Appendicularians distribution and zoogeography. In: Bone Q (ed) The biology of pelagic tunicates. Oxford University Press, Oxford, p 251-264

Flood PR, Deibel D (1998) The appendicularian house. In: Bone Q (ed) The biology of pelagic tunicates. Oxford University Press, Oxford, p 105-124

Gerber RP, Marshall N (1974) Ingestion of detritus by the lagoon pelagic community at Eniwetok Atoll. Limnol Oceanogr 19:815-824

Gonzalez HE, Sobarzo M, Figueroa D, Nöthig EM (2000) Composition, biomass and potential grazing impact of crustacean and pelagic tunicates in the northern Humboldt Current area off Chile: differences between El Niño and non-El Niño years. Mar Ecol Prog Ser 195:201-220

Gorsky G (1980) Optimisation des cultures d'áppendiculaires. Approche du métabolisme de $O$. dioica. PhD thesis, Université Pierre et Marie Curie, Paris

Gorsky G, Fenaux R (1998) The role of Appendicularia in marine food webs. In: Bone Q (ed) The biology of pelagic tunicates. Oxford University Press, Oxford, p 161-169

Graham MH (2001) Statistical significance versus fit: estimating the importance of individual factors in ecological analysis of variance. Oikos 93:505-513

Holligan PM, Harris RP, Newell RC, Harbour DS and 5 others (1984) Vertical distribution and partitioning of organic carbon in mixed, frontal and stratified waters of the English Channel. Mar Ecol Prog Ser 14:111-127

Hopcroft RR, Roff JC (1998) Production of tropical larvaceans in Kingston Harbour, Jamaica: are we ignoring an important secondary producer? J Plankton Res 20:557-569

Irigoien X, Head R, Klenke U, Meyer-Harris B, Harbour D, Niehoff B, Hirche HJ, Harris R (1998) A high frequency time series at weathership M, Norwegian Sea, during the 1997 spring bloom: feeding of adult female Calanus finmarchicus. Mar Ecol Prog Ser 172:127-137

King KR (1982) The population biology of the larvacean Oikopleura dioica in enclosed water columns. In: Grice GD, Reeve MR (eds) Marine mesocosms. Springer-Verlag, New York, p 341-351

King KR, Hollibaugh JT, Azam F (1980) Predator-prey interactions between the larvacean Oikopleura dioica and bacterioplankton in enclosed water columns. Mar Biol 56:49-57

Landry MR, Lorenzen CJ, Peterson WK (1994) Mesozooplankton grazing in the Southern California Bight. II. Grazing impact and particulate flux. Mar Ecol Prog Ser 115:73-85

Legendre L, Michaud J (1999) Chlorophyll a to estimate the particulate organic carbon available as food to large zooplankton in the euphotic zone of oceans. J Plankton Res 21:2067-2083

Longhurst AR, Sameoto D, Herman A (1984) Vertical distribution of Artic zooplankton in summer: eastern Canadian archipelago. J Plankton Res 6:137-168

López-Urrutia A, Acuña JL (1999) Gut throughput dynamics in the appendicularian Oikopleura dioica. Mar Ecol Prog Ser 191:195-205

López-Urrutia A, Irigoien X, Acuña JL, Harris R (2003) Food limitation and growth in temperate epipelagic appendicularians (Tunicata). Mar Ecol Prog Ser 252:143-157

Mackas D, Bohrer R (1976) Fluorescence analysis of zooplankton gut contents and investigation of diel feeding patterns. J Exp Mar Biol Ecol 25:77-85

Morales CE, Bautista B, Harris RP (1990) Estimates of ingestion 
in copepod assemblages: gut fluorescence in relation to body size. In: Barnes M, Gibson RN (eds) Trophic relationships in the marine environment. Proc 24th Eur Mar Biol Symp. Aberdeen University Press, Aberdeen, p 565-577 Nakamura Y (1998) Blooms of tunicates Oikopleura spp. and Dolioletta gegenbauri in the Seto Inland Sea, Japan, during summer. Hydrobiologia 185:183-192

Packard GC, Boardman TJ (1987) The misuse of ratios to scale physiological data that vary allometrically with body size. In: Feder ME, Bennett FB, Burggren WW, Hiey RB (eds) New directions in ecological physiology. Cambridge University Press, Cambridge

Paffenhöfer GA (1976) On the biology of Appendicularia of the southeastern North Sea. In: Persoone J, Jaspers E (eds) Population dynamics of marine organisms in relation with nutrient cycling in shallow waters. Proc 10th Eur Mar Biol Symp, Ostend, Belgium, Vol 2. Universa Press, Wetteren, p 437-455

Peters RH, Downing JA (1984) Empirical analysis of zooplankton filtering and feeding rates. Limnol Oceanogr 29: 763-784

Ricker WE (1984) Computation and uses of central trend lines. Can J Zool 62:1897-1905

Sanders R, Purdie DA (1998) Bacterial response to blooms dominated by diatoms and Emiliania huxleyi in nutrientenriched mesocosms. Estuar Coast Shelf Sci 46:35-48

Sato R, Tanaka Y, Ishimaru T (2001) House productivity by Oikopleura dioica (Tunicata, Appendicularia) under laboratory conditions. J Plankton Res 23:415-423

Seki H (1973) Red tide of Oikopleura in Saanich Inlet. Mer 11: 153-158

Serret P, Fernandez E, Sostres JA, Anadón R (1999) Seasonal

Editorial responsibility: Thomas Kiørboe (Contributing Editor), Charlottenlund, Denmark compensation of microbial production and respiration in a temperate sea. Mar Ecol Prog Ser 187:43-57

Shiga N (1985) Seasonal and vertical distribution of appendicularia in Volcano Bay, Hokkaido, Japan. Bull Mar Sci $37: 425-439$

Sprintall J, Tomczak M (1992) Evidence of the barrier layer in the surface layer of the tropics. J Geophys Res 97: 7305-7316

Tackx MLM, Zhu L, De Coster W, Billones R, Daro MH (1995) Measuring selectivity of feeding by estuarine copepods using image analysis combined with microscopy and Coulter counting. ICES J Mar Sci 52:419-425

Urban JL, McKenzie CH, Deibel D (1992) Seasonal differences in the content of Oikopleura vanhoeffeni and Calanus finmarchicus faecal pellets: illustrations of zooplankton food web shifts in coastal Newfoundland waters. Mar Ecol Prog Ser 84:255-264

US EPA Method 445.0. In vitro determination of chlorophyll a and pheophytin $a$ in marine and freshwater algae by fluorescence. Revision 1.2. September 1997. National Exposure Research Laboratory, Office of Research and Development, Cincinnati, $\mathrm{OH}$

Uye S, Ichino S (1995) Seasonal variations in abundance, size composition, biomass and production rate of Oikopleura dioica (Fol) (Tunicata: Appendicularia) in a temperate eutrophic inlet. J Exp Mar Biol Ecol 189:1-11

Valdes L, Moral M (1998) Time-series analysis of copepod diversity and species richness in the southern Bay of Biscay off Santander, Spain, in relation to environmental conditions. ICES J Mar Sci 55:783-792

Zar JH (1999) Biostatistical analysis, 4th edn. Prentice-Hall, Upper Saddle River, NJ

Submitted: June 13, 2002; Accepted: October 27, 2002

Proofs received from author(s): April 11, 2003 